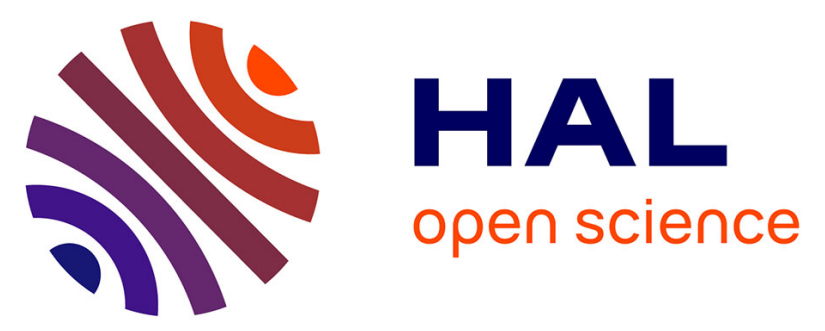

\title{
Detrital U-Pb and 40Ar/39Ar geochronology of the Connecticut Valley-Gaspé trough, southern Quebec and northern Vermont - Transitional tectonism from Salinic to Acadian orogenic cycles
}

\author{
Morgann Perrot, Alain Tremblay, Gilles Ruffet, Jean David
}

\section{To cite this version:}

Morgann Perrot, Alain Tremblay, Gilles Ruffet, Jean David. Detrital U-Pb and 40Ar/39Ar geochronology of the Connecticut Valley-Gaspé trough, southern Quebec and northern Vermont - Transitional tectonism from Salinic to Acadian orogenic cycles. Tectonophysics, 2018, 745, pp.430-452. 10.1016/j.tecto.2018.08.006 . insu-01857441

\section{HAL Id: insu-01857441 \\ https://hal-insu.archives-ouvertes.fr/insu-01857441}

Submitted on 16 Aug 2018

HAL is a multi-disciplinary open access archive for the deposit and dissemination of scientific research documents, whether they are published or not. The documents may come from teaching and research institutions in France or abroad, or from public or private research centers.
L'archive ouverte pluridisciplinaire HAL, est destinée au dépôt et à la diffusion de documents scientifiques de niveau recherche, publiés ou non, émanant des établissements d'enseignement et de recherche français ou étrangers, des laboratoires publics ou privés. 


\section{Accepted Manuscript}

TEGTONOPHYSICS

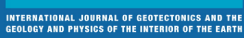

Detrital U-Pb and 40Ar/39Ar geochronology of the Connecticut Valley-Gaspé trough, southern Quebec and northern Vermont Transitional tectonism from Salinic to Acadian orogenic cycles

Morgann Perrot, Alain Tremblay, Gilles Ruffet, Jean David

PII:

S0040-1951(18)30284-1

DOI: doi:10.1016/j.tecto.2018.08.006

Reference: TECTO 127909

To appear in:

Tectonophysics

Received date:

31 January 2018

Revised date:

13 July 2018

Accepted date:

9 August 2018

Please cite this article as: Morgann Perrot, Alain Tremblay, Gilles Ruffet, Jean David , Detrital U-Pb and 40Ar/39Ar geochronology of the Connecticut Valley-Gaspé trough, southern Quebec and northern Vermont - Transitional tectonism from Salinic to Acadian orogenic cycles. Tecto (2018), doi:10.1016/j.tecto.2018.08.006

This is a PDF file of an unedited manuscript that has been accepted for publication. As a service to our customers we are providing this early version of the manuscript. The manuscript will undergo copyediting, typesetting, and review of the resulting proof before it is published in its final form. Please note that during the production process errors may be discovered which could affect the content, and all legal disclaimers that apply to the journal pertain. 


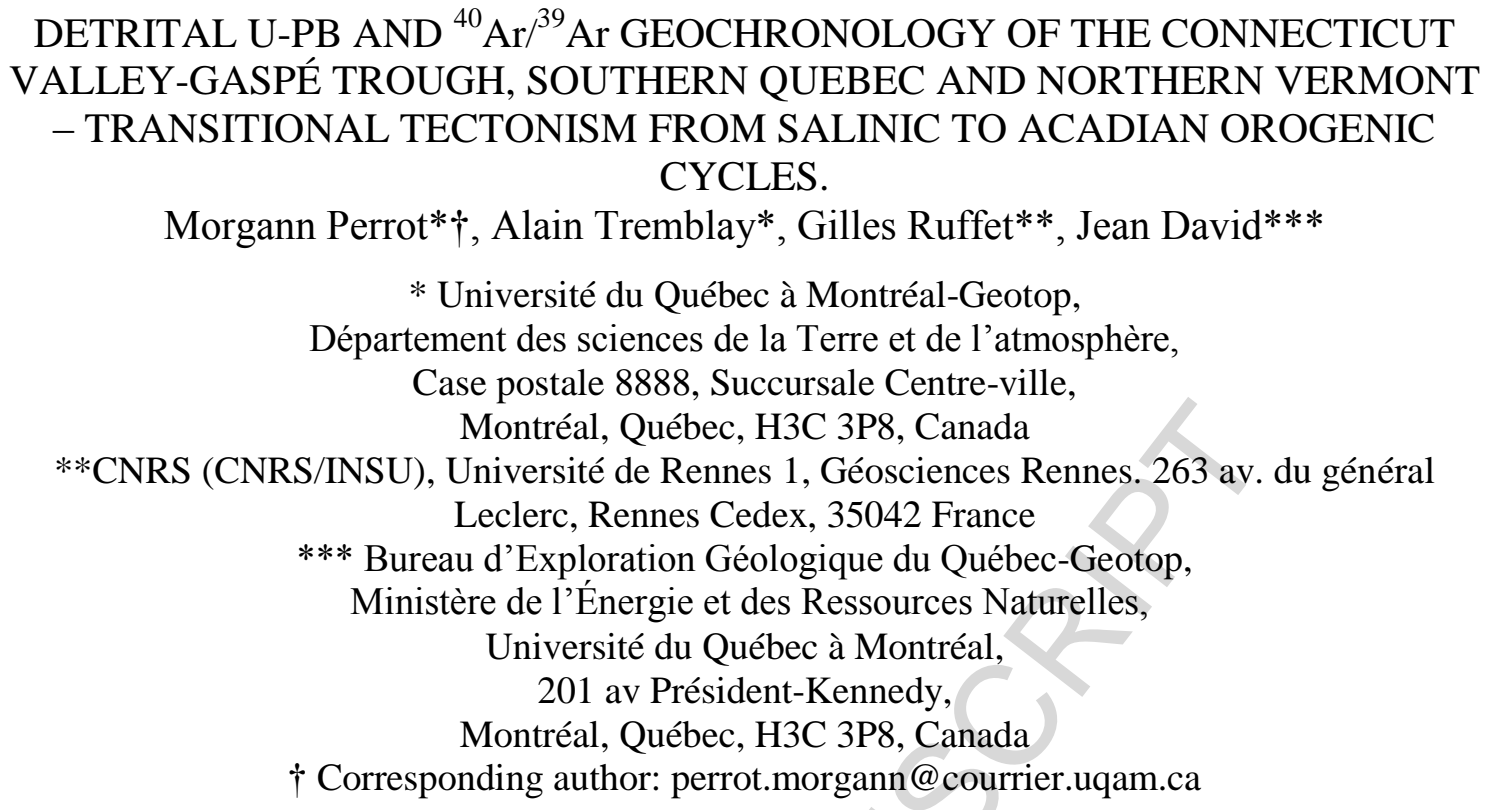

ABSTRACT.

Detrital ages constrain the timing of deposition, along-strike paleo-geographic variations and the nature of erosional sources in sedimentary basins and can be used to constrain the transition between orogenic cycles. The Connecticut Valley-Gaspé (CVG) trough is a major Upper Ordovician-to-Devonian sedimentary basin that extends for more than 1000 kilometers in the Northern Appalachians and was deposited during the Salinic and Acadian orogeneses. In Quebec and northern New England, the CVG trough is host to the Gaspé Belt and correlative units of the Connecticut Valley Sequence (CVS). In southern Quebec, the Gaspé belt sedimentation occurred during late Silurian-to-Early Devonian crustal extension related to the Salinic orogeny. This study reports detrital $\mathrm{U} / \mathrm{Pb}$ zircon and ${ }^{40} \mathrm{Ar} /{ }^{39} \mathrm{Ar}$ muscovite ages from the Ayers Cliff and Compton formations, Quebec and the correlatives Waits River and Gile Mountain formations, Vermont. Detrital zircon ages suggest that proximal early Silurian-to-Devonian erosional sources were submerged during sedimentation, which is consistent with an extension-related marine transgression marked by the Ayers Cliff and Waits River formations. The lack of Ediacaran zircons in the Ayers Cliff Formation contrasts the Waits River Formation, suggesting that the nature of erosional sources varied during deposition of the lowermost part of the basin. Stratigraphically higher Compton and Gile Mountain formations have similar detrital zircon provenance suggesting homogenization of detrital contributions. This is attributed to the encroachment of Avalonian terranes and ongoing erosion, probably during uplift of Laurentia and Avalonian terranes leading to foreland basin development and deposition of the uppermost part of the Compton and Gile Mountain formations which yielded youngest mean ages of ca. $413 \mathrm{Ma}$ and ca. $401 \mathrm{Ma}$, respectively. Low-grade metamorphic conditions allow the preservation of detrital ${ }^{40} \mathrm{Ar} /{ }^{39} \mathrm{Ar}$ muscovite ages which highlight the contribution of erosional sources that experienced Grenvillian, Taconian and Salinic metamorphism. 


\section{Introduction}

Detrital mineral geochronology is an essential analytical tool for the comprehensive study of syn-orogenic sedimentary basins. It yields information on the availability of erosional sources at the time of deposition and thus provides critical data on the tectonic evolution of mountain belts, particularly for source regions that have been affected by metamorphism or that has been removed by tectonism or erosion following basin development.

In the Quebec Appalachians, the Connecticut Valley-Gaspé (CVG) trough is host to the Gaspé Belt, the remnant of a major Late Ordovician - Middle Devonian sedimentary basin of the Northern Appalachian orogen (Bourque et al., 1995; 2000), which extends from Gaspé Peninsula to New England where it is known as the Connecticut Valley sequence (CVS, Fig. 1 ; Rankin et al., 2007; McWilliams et al., 2010). In southern Quebec, the formation of the CVG trough was initiated during a late Silurian episode of crustal extension (Tremblay and Pinet, 2005, 2016), which has been more or less coeval with late stages of the Salinic orogeny as documented in the Canadian Maritimes provinces (e.g. van Staal et al., 1998; van Staal and Barr, 2012). Both the Gaspé Belt and the CVS have been subsequently affected by the Middle Devonian Acadian orogeny.

The timing of deposition, along-strike paleo-geographic variations and the nature of erosional sources that contributed to the formation of the Gaspé Belt and the CVS are key elements to document in order to better characterize the tectonic setting of the CVG trough in the Northern Appalachians. This also has significant implications for the understanding of the Middle Devonian Acadian orogeny, the reconstitution of time 
correlative sedimentary units, and to better understand tectonic links along the strike of the orogen (see for example the work of Waldron et al., 2018). The age of formation of the CVG trough in southern Quebec and adjacent Vermont is currently poorly constrained, mainly because these rocks are almost entirely devoid of index fossils, and due to strong deformation and greenschist to upper amphibolite facies metamorphism during the Acadian orogeny. The CVS has been recently investigated by detrital zircon U-Pb dating in south-central Vermont (McWilliams et al., 2010). In southern Quebec, the Acadian regional metamorphism is at lower grade (i.e., sub- to greenschist facies) than in New England, and thus these rocks preserve detrital muscovite ${ }^{40} \mathrm{Ar} /{ }^{39} \mathrm{Ar}$ ages which, combined with detrital zircon $\mathrm{U}-\mathrm{Pb}$ ages, permit to better constrain the nature of erosional sources. In this contribution, we present the results of a U-Pb and ${ }^{40} \mathrm{Ar} /{ }^{39} \mathrm{Ar}$ geochronological study of detrital zircon and muscovite of the CVG trough in southern Quebec and northern Vermont. The terms Gaspé Belt and Connecticut Valley sequence (CVS) are used herein to refer to the present-day distribution of Silurian and Devonian rocks in Quebec and New England, respectively, whereas the term CVG trough (Bradley, 1983; Tremblay and Pinet, 2005) is used to refer to the basin within which these rocks were deposited.

\section{Geological context}

In the Northern Appalachians, the CVG trough varies from ten to approximately a hundred kilometers-wide over a strike length of more than $1000 \mathrm{~km}$, from the Gulf of St. Lawrence to Long Island Sound. It is the remnant of a much broader basin that had episodic Middle Paleozoic connections with the St. Lawrence Platform to the NW and the Merrimack trough to the SE (Tremblay and Pinet, 2016). In the Gaspé Peninsula, the 
Gaspé Belt crops out within three major structures: the Connecticut Valley-Gaspé synclinorium (or trough), the Aroostook-Percé anticlinorium and the Chaleurs Bay synclinorium (Williams, 1995). Only the CVG trough is continuous into southern Quebec and New England (Fig.1 to 3). There, both the Gaspé Belt and the CVS unconformably overly, or are in fault contact with Lower Paleozoic rocks of the Humber zone and/or the Dunnage zone (i.e the Notre-Dame subzone; Williams, 1979) to the NW, and of the Dunnage zone (i.e., the Exploits subzone) and/or the Gander zone to the SE. The Humber and Dunnage zones represent, respectively, the remnants of the Laurentian continental margin and of peri-Laurentian (i.e., Notre-Dame subzone) and peri-Gondwanan (Exploits subzone) terranes whereas the Gander zone is interpreted as the vestige of a periGondwanan microcontinent outboard of Laurentia (Williams, 1979). In the Canadian Appalachians, the contact between Laurentian- and Gondwanan-affinity terranes is known as the Red Indian Line and is interpreted as a major tectonic boundary (van Staal et al., 2013). In New England, the Red Indian Line is interpreted to be located along the eastern flank of the Chain Lakes massif of western Maine (van Staal et al., 1998), whereas southward it is shown as a buried structure west of the Bronson Hill anticlinorium (e.g.Tucker and Robinson, 1990). Macdonald et al. (2014) recently proposed, however, that the Red Indian Line in Vermont is located west of the CVS, more precisely west of and beneath the Moretown Formation, which they re-interpreted as being related to Gondwana on the basis of detrital U-Pb zircon ages. In Vermont, this boundary is also known as the Coburn Hill - Whitcomb Summit thrust, a fault marking the contact between the Stowe and Moretown formations (see Ratcliffe et al., 2011). 
The stratigraphy of the Gaspé Belt is best known in Gaspé Peninsula where Acadian metamorphism is of very-low grade and where there are well-defined biostratigraphic constraints (see Bourque et al., 1995; 2000). Tremblay and Pinet (2016) subdivided the Gaspé Belt of the Quebec Appalachians into, a lower sequence consisting of Upper Ordovician to lower Silurian deep-water, fine-grained siliciclastic and carbonates facies (the Cabano, Honorat and Matapedia groups), and an upper sequence consisting of Silurian to Middle Devonian, shallow to deep-water shelf and basin facies carbonates, siliciclastic and nearshore to terrestrial facies molassic series (known as the Chaleurs Group in Gaspé Peninsula and the Saint-Francis Group in southern Quebec). In southern Quebec and New-England, the sedimentary succession of the Gaspé belt and CVS is considered as part of the late Silurian and Devonian stratigraphy defined in the Gaspé Peninsula (Bourque et al., 2000; Lavoie, 2004; Tremblay and Pinet, 2016).

In Quebec, the north and northwestern boundary of the CVG trough is marked by major faults, such as the Troisième-Lac and Shickshock-Sud faults in Gaspé Peninsula, and the La Guadeloupe fault in southern Quebec, showing dextral transcurrent and westverging reverse fault motions in Gaspé and southern Quebec, respectively (Malo et al., 1995). Some of these faults (i.e., the La Guadeloupe and Shickshock-Sud faults) may represent reactivated early Silurian normal faults (Tremblay and Pinet, 2005; Pinet, 2013; 2016). In Vermont, the La Guadeloupe fault merges into the "Richardson memorial contact" (RMC), a Silurian unconformity (e.g. Cady, 1950; White and Jahns, 1950; Doll et al., 1961; Hatch, 1988a) that corresponds to the Taconian Line of Hatch et al. (1982), and which is locally crosscut by the east-verging Dog River fault zone (Fig. 2, Walsh et al., 2010). 
The eastern boundary of the CVG trough is more dubious, especially in northern Maine and New Brunswick where the lithological units of the Gaspé Belt merge into the Silurian-Devonian sequences of the Central Maine Basin (CMB ; Hibbard et al., 2006 ; i.e. the Merrimack trough of Tremblay and Pinet, 2005). In southern Quebec and NewEngland, the CVG trough is separated from the CMB by faults (e.g., the Thrasher Peaks and Monroe faults) and outliers of pre-Silurian rocks such as the Chain Lakes Massif and/or the Bronson Hill/Boundary Mountains anticlinoria (Figs. 1 and 2, Tucker and Robinson, 1990; Moench and Aleinikoff, 2003; Rankin et al., 2013).

\subsection{Stratigraphy and age constraints}

Southern Quebec. Some of the rock units of the Gaspé Belt as defined by Bourque et al. $(1995,2000)$ are exposed to the northwest of the La Guadeloupe fault. These rocks are the Saint-Luc and Cranbourne formations in the Beauce area (north of the area shown in Fig. 1), and the Lac Aylmer Formation and Glenbrooke Group in southernmost Quebec (Figs 1 and 3). East of the La Guadeloupe fault, the Gaspé Belt crops out into the CVG trough and is made up of sedimentary and volcanic rocks of the St. Francis Group, and, east of the Bella fault, of the Frontenac and Clinton River formations (Fig.1, Lavoie, 2004).

The St. Francis Group is subdivided into three units, from base to top, the LacLambton, Ayers Cliff and Compton formations (Figs. 1 and 3; Lavoie, 2004). The LacLambton Formation comprises alluvial conglomerate, fine-grained siliciclastic rocks, subtidal carbonates and shelf limestones. The occurrence of corals and brachiopods in the upper part of that formation indicates a Pridolian age of deposition (Fig. 3, Lavoie and Bourque, 1992). The Lac-Lambton Formation is structurally overlain by the Ayers Cliff 
Formation (Lavoie and Tremblay, 1993) which consists of interbedded impure limestone and calcareous mudstone (Fig. 4A). A single occurrence of Chitinozoan fauna found toward the top of this unit provided a late Lochkovian-early Pragian age (Asselin, 2002).

The Compton Formation overlies the Ayers Cliff Formation and consists of interlayered quarzitic to feldspathic sandstone and black slate. From base to top, it is divided into three informal members (Lebel and Tremblay, 1993), the Milan, Lac-Drolet and Ludger members. The Milan member is characterized by thick beds of crosslaminated sandstone with mudstone interbeds (Fig. 4 B to D) that grade upward into feldspar-rich sandstone and mudstone of the Lac-Drolet member, (Figs. 4E and F), which is itself overlain by the black mudstone-dominated sequence of the Saint-Ludger member. The age of the Compton Formation is uncertain. The local occurrence of plant remnants (Hueber et al., 1990) suggests that it cannot be older than late Silurian - Early Devonian, which would be consistent with a single detrital U/Pb zircon age of $396 \pm 5$ Ma (late Early Devonian) measured by de Souza et al. (2014), although this latter age is disputable (see following). The upper part of the Compton Formation, the Lac-Drolet member, yielded Early Devonian Chitinozoans species (Fig. 3, Asselin, 2001; Lavoie and Asselin, 2004).

The Frontenac and Clinton River formations crop out to the southeast of the St. Francis Group, in the hanging wall of the Bella fault (Fig. 1). The Frontenac Formation has been interpreted as a lateral equivalent of the Milan member (Lafrance, 1995). It mainly differs from the latter by the occurrence of basaltic volcanic rocks with withinplate geochemical affinities (Desjardins, 1994), interlayered with siliciclastic rocks. In Quebec, the Frontenac Formation yielded a poorly-preserved late Lochkovian-early 
Praguian Chitinozoan fauna (van Grootel et al., 1995; Asselin, 2002). In adjacent New Hampshire, (Dorais et al., 2017) obtained a U-Pb zircon crystallization age of $432 \pm 8 \mathrm{Ma}$ from that same unit. Towards the southeast, the Frontenac Formation is in fault contact with the lower(?) Silurian Clinton River Formation, which consists of MORB basalts (Desjardins, 1994) interlayered with feldspathic sandstone. Towards the southeast, the CVG trough is in tectonic contact with the Chain Lakes Massif, interpreted as an outlier of Laurentia (Tremblay and Pinet, 2005; de Souza and Tremblay, 2010) or a microcontinent of Laurentian affinity (Waldron and van Staal, 2001).

In summary, late Silurian to Early Devonian ages are currently loosely attributed to the sedimentary rocks of the CVG trough. The lower age limit of these rocks is unknown, but their upper age limit is constrained by the timing of regional metamorphism (375-380 Ma; Tremblay et al., 2000) and by 384-to-374 Ma granitic intrusions (Simonetti and Doig, 1990).

Northern New England. In Vermont and New Hampshire, the CVS is made up, from base to top, of the Shaw Mountain, Northfield, Waits River and Gile Mountain formations (Figs. 1 and 3, see McWilliams et al., 2010 and references therein). Following the interpretation of Hatch (1988b) and Lyons et al. (1997), the Meetinghouse Slate member of western New Hampshire is included in the Gile Mountain Formation. The stratigraphic position of the Northfield Formation relative to the Meetinghouse Slate member and other formations is, however, still debated (see McWilliams et al., 2010).

According to recent detrital and magmatic zircons dating and interpretations (Rankin and Tucker, 2009; McWilliams et al., 2010), the stratigraphic framework of the CVS is as follow: the Shaw Mountain conglomerate and the Northfield Formation grade 
eastward (and upward) into the Waits River and Gile Mountain formations, the two main stratigraphic units of the CVS, both correlatives with the Ayers Cliff and Compton formations, respectively.

The Waits River Formation consists of interbedded grayish metapelite and impure quartzitic limestone, for which youngest single-grain detrital zircon ages measured by McWilliams et al. (2010) are $418 \pm 7$ and $415 \pm 2$ Ma (Fig. 2). The Gile Mountain Formation is divided into two facies (Fig. 1), the Sharon facies, a thickly-bedded sequence of quartzite, metapelite and minor calcareous phyllite and impure limestone, and the Royalton facies, a turbiditic sequence of interbedded quartzite and metapelite. The youngest detrital zircon age population, obtained from the Royalton facies, is $409 \pm 5 \mathrm{Ma}$ (Fig. 2, McWilliams et al., 2010).

Both the Waits River and Gile Mountain formations contain discontinuous horizons of mafic volcanic rocks (e.g. Doll et al., 1961; Armstrong et al., 1997). The Standing Pond volcanic member of the Waits River Formation has geochemical characteristics compatible with a rift setting (Slack, 1994; Karabinos, 1998). Aleinikoff and Karabinos (1990) obtained a U-Pb zircon age of $423 \pm 4$ Ma from a felsic dyke crosscutting the Standing Pond volcanics, thus providing a late Silurian minimum age for the Waits River Formation.

Towards the top of the CVS, the Meetinghouse Slate member of the Gile Mountain Formation hosts rhyolitic flows that yielded a U-Pb zircon age of $407 \pm 3 \mathrm{Ma}$ (Rankin and Tucker, 2009). In northeastern Vermont and adjacent New Hampshire, the CVS includes metasedimentary and metavolcanic rocks of the Frontenac Formation which are contiguous with the southern Quebec sequence. In New Hampshire, Silurian 
(?) metasedimentary and metavolcanic rocks of the Bronson Hill anticlinorium include the Clough, Fitch and Littleton formations (e.g. Elbert et al., 1988; Rankin and Tucker, 2009; Walsh et al., 2012; Rankin et al., 2013). The Clough Formation is made up of conglomerate and quartzite (Elbert et al., 1988) and is possibly correlative with the Shaw Mountain Formation, whereas the Littleton Formation can be correlated, at least in parts, with the Waits Rivers-Gile Mountain formations (see Rankin et al., 2007; Bradley and O'Sullivan, 2016).

Voluminous Middle Devonian granitic intrusions of the New Hampshire Plutonic Suite (Ratcliffe et al., 2011) cut across the Silurian-Devonian rocks of the CVS (Fig. 1). In Vermont, Rb-Sr ages from the New Hampshire Plutonic Suite range from $370 \pm 17 \mathrm{Ma}$ to $390 \pm 14$ (Arth and Ayuso, 1997) and U-Pb zircon ages range from $392 \pm 6$ Ma to 365 \pm 5 Ma (Moench and Aleinikoff, 2003; Aleinikoff et al., 2011; Ratcliffe et al., 2011). These ages overlap U-Pb zircon ages of similar granitic intrusions of southern Quebec. A recent geochronological study on the Knox Mountain pluton, interpreted to be a syntectonic intrusion, yielded a electron microprobe $\mathrm{U}-\mathrm{Th}-\mathrm{Pb}$ dating of monazite age of $377 \pm 5.2 \mathrm{Ma}$ (Lagor, 2016).

\subsection{Regional deformation and metamorphism}

The Gaspé Belt and the CVS have been affected by Middle Devonian Acadian metamorphism and deformation (Fig. 2), with however significant along-strike variations in metamorphic intensity and structural complexity (Tremblay et al., 2000). In southern Quebec, regional deformation is characterized by $\mathrm{NW}$-verging $\mathrm{F}_{1}$ folds with an $\mathrm{S}_{1}$ axialplanar schistosity. Metamorphic minerals are hosted by $\mathrm{S}_{1}$ and correspond to Acadian metamorphism that peaked at ca. 380-375 Ma (Tremblay et al., 2000). Regional 
metamorphism varies from prehnite-pumpellyite facies in the north to greenschist facies in southernmost Quebec. In the Sherbrooke and La Patrie areas and southward (Fig. 1), F folds are superimposed by SE-verging $F_{2}$ folds. Where present, the axial-planar $S_{2}$ crenulation cleavage (Fig. 4) is defined by the reorientation of platy minerals, mostly muscovite. $\mathrm{D}_{2}$-related metamorphism seems to be overprinted by, or coeval with, contact metamorphism developed around the Middle Devonian granitic plutons. $\mathrm{D}_{2}$ structures are locally overprinted by a late-stage fracture or crenulation cleavage, $S_{3}$ (Fig. 4).

In the CVS, regional metamorphism attains amphibolite facies. It varies from the garnet zone in Vermont to the kyanite-staurolite zone in northern Massachusetts and the kyanite-staurolite and sillimanite-muscovite zones in southern Massachusetts and Connecticut (e.g. Zen et al., 1983; Osberg, 1989; Growdon et al., 2013). In Vermont, Acadian regional deformation fabrics can be correlated with those of southern Quebec but are much more penetrative (Tremblay et al., 2000). There is an early generation of $\mathrm{NW}$-verging folds associated with a regional $\mathrm{S}_{2}$ schistosity (that correlates with $\mathrm{S}_{1}$ of southern Quebec), which is superimposed by SE-verging backfolds related to a welldeveloped $S_{3}$ crenulation cleavage (corresponding to $S_{2}$ in southern Quebec), and by latestage, north-trending metamorphic domes with an axial-planar $\mathrm{S}_{4}$ crenulation cleavage (corresponding to $\mathrm{S}_{3}$ in southern Quebec) (White and Jahns, 1950; Hatch and Stanley, 1988; Osberg, 1989; Tremblay et al., 2000; Walsh et al., 2010). In Vermont, K/Ar and ${ }^{40} \mathrm{Ar} /{ }^{39} \mathrm{Ar}$ metamorphic ages vary from $385-376 \mathrm{Ma}$ (Laird et al., 1984) to 376-365 Ma (Sutter et al., 1985; Lagor, 2016). ${ }^{40} \mathrm{Ar} /{ }^{39} \mathrm{Ar}$ cooling ages of $388 \mathrm{Ma}$ and $376 \mathrm{Ma}$ have also been reported from Massachusetts and Connecticut (Laird et al., 1984; Hames et al., 1991). Armstrong et al. (1992) suggested that Acadian metamorphism (that is related to 
the $\mathrm{D}_{2}$ deformation as described above) peaked approximately at $390 \mathrm{Ma}$ in New England, which would be then approximately 10 m.y. older than in southern Quebec.

\section{3. $\mathrm{U} / \mathrm{Pb}$ and ${ }^{40} \mathrm{Ar}^{/ 39} \mathrm{Ar}$ geochronology}

In the following, we present the U-Pb dating of magmatic zircon from the Averill pluton, and a $\mathrm{U}-\mathrm{Pb}$ and ${ }^{40} \mathrm{Ar} /{ }^{39} \mathrm{Ar}$ geochronological study of detrital zircon and muscovite, respectively, performed in the sedimentary rocks of the Connecticut Valley Gaspé trough in Quebec and Vermont. At the Quebec-Vermont border, the undated Averill pluton crosscuts both the Gaspé Belt and the CVS, and was sampled for U/Pb zircon dating (sample 14AV01). In terms of strategy for the detrital minerals geochronological study, sampling was carried out along three NW-SE trending transects, and from base to top of the stratigraphic sequence along each transect. From north to south, the three transects are (Fig. 1), (1) the La Patrie transect (samples 14MP42, 14MP70, 14MP57 and 14MP89), (2) the Coaticook transect (samples 13MP05, 13MP14, 13MP15, and 13MP26), both in southern Quebec, and (3) the St. Johnsbury transect in northern Vermont (samples 14VT05, 14VT07 and 14VT10). In southern Quebec, two samples are from the Ayers Cliff Formation whereas five were collected in the Compton Formation. Among the latter, two are from the Milan member and three from the LacDrolet member. In Vermont, two samples were collected in the Waits River Formation and one in the Gile Mountain Formation. Samples locations are shown in Figure 1 whereas structural and stratigraphic relationships are displayed on Figures 2 and 3.

\subsection{Analytical procedures}

Approximately $10 \mathrm{~kg}$ of siltstone and/or sandstone were collected at each sampling site. The samples were crushed with a jaw crusher. Approximately $200 \mathrm{~g}$ of 
crushed rock was kept for the ${ }^{40} \mathrm{Ar} /{ }^{39} \mathrm{Ar}$ analysis (except for the Averill Pluton, sample 14AV01), whereas the remaining fraction was used for zircon grains separation.

$\boldsymbol{U}-\boldsymbol{P b}$ analyses. $\mathrm{U}-\mathrm{Pb}$ analyses were conducted by isotope dilution thermal ionization mass spectrometry (ID-TIMS) and laser ablation (HR-LA-MC-ICP-MS) at the Geotop geochronological laboratory (Université du Québec à Montréal). The crushed rock kept for zircon grains separation was refined in a disc grinder, and then passed on a Wilfley table, a Frantz magnetic separator, and in heavy liquids. Using a binocular microscope, zircon crystals were extracted by handpicking from each sample, chosen by morphological characteristics for the dating of the Averill pluton, and randomly selected for detrital analyses.

For the dating of the Averill pluton, the selected grains were annealed and chemically abraded following Mattinson (2005). The abraded crystals were washed, spiked, and then dissolved (David et al., 2006). Dissolved zircons were chemically purified using microcolumns and anion-exchange resin adapted from Krogh (1973). After being dried down, the $\mathrm{U}-\mathrm{Pb}$ solutions were loaded on degassed $\mathrm{Re}$ filaments and measured on a VG Sector-54 mass spectrometer using Daly ion counter.

For detrital analyses, zircons were mounted in epoxy, polished and analysed by laser ablation, using a multiple ion counting Faraday collector array (for details, see Table 1 where metadata are included as recommended by Horstwood et al., 2016). Zircon cathodoluminescence (CL) imagery was performed on a scanning electron microscope (SEM) to highlight growth zoning within individual grains. Most zircons show oscillatory and sector zoning, but only some of them show metamorphic rims overgrowths. Most of the time, the cores of randomly selected zircons were analyzed. We were particularly 
careful to avoid fractures and inclusions-rich domains within zircon grains. The zircon standard used for calibration of the ${ }^{206} \mathrm{~Pb} /{ }^{238} \mathrm{U}$ ratio was 91500 (Wiedenbeck et al., 1995). All data reduction was performed using the Iolite data reduction package (Paton et al., 2011). ${ }^{206} \mathrm{~Pb}^{*} /{ }^{238} \mathrm{U}$ ages are used for zircons younger than $c a .1000 \mathrm{Ma}$, whereas ${ }^{206} \mathrm{~Pb}^{*} /{ }^{207} \mathrm{~Pb} *$ ages are used for zircons older than $c a .1000 \mathrm{Ma}$. To facilitate comparison, the same rejection criteria have been used to filter all $\mathrm{U}-\mathrm{Pb}$ data: a filter for both large age uncertainties and $\left({ }^{207} \mathrm{~Pb} /{ }^{206} \mathrm{~Pb}\right) /\left({ }^{206} \mathrm{~Pb} /{ }^{238} \mathrm{U}\right)$ age discordance. Concordia age with a $2 \sigma$ uncertainty of less than $10 \%$ and analyses with a $30 \%$ discordance $\left(1-\left({ }^{206} \mathrm{~Pb}^{*} /{ }^{238} \mathrm{U}\right.\right.$ age $/{ }^{207} \mathrm{~Pb} * /{ }^{206} \mathrm{~Pb} *$ age) $\mathrm{x} 100$ ) of the centroid were kept for probability density distribution diagrams. Rather generous cut-offs were selected to avoid bias during the final set of ages (see Gehrels et al., 2011). However, analysis with a $10 \%$ discordance or less was kept for calculation on maximum age of sedimentation as well as analyses that overlap with the 1:1 concordance line (Spencer et al., 2016). For consistency, comparison and clarity, both $30 \%$ and $10 \%$ concordant data are plotted on figures 6 to 8 .

Analytical data were plotted on $\mathrm{Pb} * / \mathrm{U}$ Concordia and probability density plots (Figs. 5 to 8) using Isoplot 4.2 (Ludwig, 2012). All results are presented in table 2 and 3 (in supplementary material) for TIMS and HR-LA-MC-ICP-MS analysis, respectively.

${ }^{40}$ Ar ${ }^{39}$ Ar analysis. Mica single grains used for ${ }^{40} \mathrm{Ar} /{ }^{39} \mathrm{Ar}$ laser probe step heating experiments were randomly extracted by handpicking under a binocular microscope from 0.1 to $0.5 \mathrm{~mm}$ fractions for detrital white micas from sedimentary crushed rock samples. The analytical procedure is detailed in Castonguay et al. (2001, 2007). Detrital mica grains collected from samples of the St. Francis Group (Gaspé Belt) are usually white to yellow translucent crystals, whereas metamorphic mica grains are grey to dark grey 
crystals. Five to seven grains have been analysed for each sample, but in this study, only the single grain detrital ages of the Gaspé Belt are presented.

Apparent age errors are plotted at the $1 \sigma$ level and do not include the errors on the ${ }^{40} \mathrm{Ar}^{*} /{ }^{39} \mathrm{Ar}_{\mathrm{K}}$ ratio and age of the monitor and decay constant. Plateau ages were calculated if $70 \%$ or more of the ${ }^{39} \mathrm{Ar}_{\mathrm{K}}$ was released in at least three or more contiguous steps, the apparent ages of which agreeing to within $1 \sigma$ of the integrated age of the plateau segment (Ruffet et al., 1991). Pseudo-plateau (PP) ages can be defined with less than $70 \%$ of the ${ }^{39} \mathrm{Ar}_{\mathrm{K}}$ released and possibly less than three contiguous steps (Cheilletz et al., 1999). Errors on the ${ }^{40} \mathrm{Ar}^{*} /{ }^{39} \mathrm{Ar}_{\mathrm{K}}$ ratio and age of the monitor and decay constant are included in the final calculation of the error range on the Plateau and PP ages or apparent ages individually cited. Analytical data and parameters used for calculations (e.g., isotopic ratios measured on $\mathrm{K}, \mathrm{Ca}$ and $\mathrm{Cl}$ pure salts; mass discrimination; atmospheric argon ratios; J parameter; decay constants) and reference sources are available in the supplementary data repository.

\section{2. $\mathrm{U}-\mathrm{Pb}$ results}

The Averill pluton. The Averill pluton (Fig. 1) is a large granitic intrusion that cross-cuts the St. Francis Group at the Quebec-Vermont border. The analyzed sample is from a homogeneous outcrop of biotite-muscovite granite in the Lyster Lake area, at the Quebec-Vermont border (Fig. 1). This sample yielded a single, idiomorphic and colourless zircon population characterized by short or very elongated prismatic sections with pyramidal terminal faces. Scarce spherical and translucent inclusions are present within zircon grains whereas some occurrences of xenomorphic crystals possibly represent mixed crystals with older nuclei. Three fractions were analyzed from the short 
and elongated prisms of zircons. These zircons have relatively high uranium concentrations (160 to $515 \mathrm{ppm}$ ) and variable $\mathrm{Th} / \mathrm{U}$ ratios $(0.231$ to 0.407$)$. The $\mathrm{U}-\mathrm{Pb}$ results are $-0.08 \%$ to $-0.17 \%$ concordant. We obtained a Concordia age of $367.8 \pm 0.3 \mathrm{Ma}$ (Fig. 5), which we interpret as corresponding to the crystallization and emplacement of the Averill pluton.

Detrital zircon. Detrital zircon ages obtained from the whole set of samples yielded three broadly-defined populations, (1) 390 to $550 \mathrm{Ma}$, (2) 900 to $2000 \mathrm{Ma}$, and (3) $>2.5$ Ga (Figs. 6 to 8; table 1). In the following section, results obtained from samples of the Gaspé Belt of southern Quebec will be presented first, followed by those obtained in correlative rocks of the CVS in northern Vermont.

Southern Quebec. The two samples of the Ayers Cliff Formation (Fig. 1), 14MP42 on the La Patrie transect (Fig. 6) and 13MP05 on the Coaticook transect (Fig. 7), were both collected from coarse-grained lithic sandstone beds towards the top of the limestone sequence. These samples yielded abundant grey zircons with a frosted luster and blunt shapes, varying from well-rounded to prismatic with some amber to reddish-brown zircons showing well-rounded shapes. 126 and 119 analyses (in samples 14MP42 and 13MP05, respectively) out of the 130 analysed zircon grains from each sample were kept for detrital age calculations (table 1; Fig. 6A and 7A).

$\mathrm{U}-\mathrm{Pb}$ ages distribution for these samples shows a broad Precambrian ages population and very few Paleozoic ages (Figs. 6 and 7). Approximately $85 \%$ of the dated zircons correspond to ages ranging from ca. $1950 \mathrm{Ma}$ to ca. $925 \mathrm{Ma}$ (Figs.6A and 7A), with only 2 zircon grains yielding ages of ca. 2 Ga in sample 13MP05. Both samples also 
show some zircons with ages clustering around $2.5 \mathrm{Ga}$. For sample 14MP42 (Fig. 6A), the dominant Precambrian age peak is at $1059 \mathrm{Ma}$, whereas it is $1164 \mathrm{Ma}$ for sample 13MP05 (Fig. 7A). In both samples, less than 5\% of zircons yielded ages between 512 and $431 \mathrm{Ma}$. The youngest age peaks (which should be defined by at least three zircons as suggested by Dickinson and Gehrels, 2009) are $472 \mathrm{Ma}$ in sample $14 \mathrm{MP} 42$ and $452 \mathrm{Ma}$ in sample 13MP05, which is significantly older than the late Lochkovian-early Pragian (415-410 Ma) depositional age inferred from the Chitinozoan fauna (Lavoie and Asselin, 2004).

Samples of the Compton Formation were collected from lithic sandstone beds of the Milan member (samples 14MP70, 13MP14 and 13MP15) and feldspathic wackes of the Lac-Drolet member (samples 14MP89, 14MP57 and 13MP26). All samples of the Milan member correspond approximately to the same stratigraphic level, although sample 14MP70 was taken closer to the contact with the overlying Lac-Drolet member than other samples. In the Lac-Drolet member, sample 14MP57 is from the lower part of the sequence whereas samples 14MP89 and 13MP26 are from the upper part.

Except for sample 13MP14, which yielded a set of zircon grains with columnar shapes, the Milan member yielded clear to pinkish-brownish zircon grains with prismatic to rounded shapes and smooth edges. 102 analyses out of 130 analysed zircon grains from sample 14MP70 were kept for age calculations (Fig. 6B), whereas 111 and 109 analyses were kept for samples 13MP14 and 13MP15, respectively (Figs. 7B and C). The probability density distribution diagrams for these three samples yield similar patterns, showing broad populations of Precambrian (with a few proportion of Ediacaran ages) and Paleozoic ages. Roughly $60 \%$ of zircon grains yielded ages of ca. 1200-to-950 Ma, with a 
minor amount of zircons yielding Archean ages. Approximately 5\% of zircon grains yielded ages of ca. 650-to-540 Ma, whereas about 30\% yielded ages varying between 515 and 422 Ma, with two scattered ages at 416 and 398 Ma. The youngest age peaks of these three samples are $419 \mathrm{Ma}$ (14MP70, Fig. 6B), $456 \mathrm{Ma}$ (13MP14, Fig. 7B) and $465 \mathrm{Ma}$ (13MP15, Fig. 7C), the latter two ages being significantly older than the inferred fossilsbased depositional ages (i.e. <419 Ma according to Lavoie and Asselin, 2004). Note also that these ages are significantly older than the youngest detrital zircon age population of $396 \pm 5$ Ma obtained by de Souza et al. (2014) on the Milan member.

The three samples (14MP57, 14MP89 and 13MP26) of the Lac-Drolet member (Fig. 1) yielded two different types of zircon grains, (1) clear to pinkish-brownish zircons with prismatic to rounded shapes and smooth edges, as in 14MP57, and (2) clear zircons, most of them with an elongate columnar shape and sharp edges or an elliptic to rounded shape and smooth edges, as in 13MP26 and 14MP89. 112 analyses of a total of 130 analysed zircon grains from sample 14MP57 were kept for calculations (Figs. 6C and 7D). This sample is characterized by broad populations of Precambrian and Paleozoic ages, with approximately $60 \%$ of the zircon grains yielding 1878 to 979 Ma with age clusters at $1081 \mathrm{Ma}$ and $1623 \mathrm{Ma}$ (Fig. 6D), and a minor proportion of Archean grains. Approximately $30 \%$ of these zircons yielded Paleozoic ages, with a dominant age peak at $462 \mathrm{Ma}$ and a minor, younger peak at around $415 \mathrm{Ma}$ (Fig. 6C). 68 analyses of sample 14MP89 (Fig. 6D) and 71 analyses of sample 13MP26 (Fig. 7C) of a total of 130 analysed zircon grains from each sample were kept for calculations. As compared to 14MP57 and samples from the Milan member, these two latter samples show a distinctive probability density distribution, with much less abundant Precambrian ages between ca. 
1000 and $1800 \mathrm{Ma}$ and a more significant proportion of Paleozoic ages. More than $50 \%$ of zircon grains yielded ages varying between 675 and $400 \mathrm{Ma}$, with well-defined age peaks at $481 \mathrm{Ma}$ and $417 \mathrm{Ma}$ in sample 14MP89 (Fig. 6D), and at $639 \mathrm{Ma}, 509 \mathrm{Ma}, 454$ Ma and $411 \mathrm{Ma}$ in sample 14MP26 (Fig. 7C).

Northern Vermont. In Vermont, samples 14VT05 and 14VT07 were collected from meters-thick beds of light grey calcareous quartzite interbedded within the marbledominated sequence of the Waits River Formation. These two samples yielded abundant clear zircons with a frosted luster, rounded edges and elliptical to discoidal, elongated prismatic shapes. 120 analyses of sample 14VT05 and 110 analyses of sample 14VT07 out of 130 zircon analysed grains from each sample were used for age calculations. The probability density distribution diagrams are similar for the two samples (Fig. 8A and B), both being characterized by a small but broadly-distributed proportion of Precambrian ages and a major peak of Paleozoic ages population. Both samples show Precambrian age peaks between 913 and 1964 Ma with some grains older than $2 \mathrm{Ga}$. The dominant youngest age peaks are $414 \mathrm{Ma}$ and $473 \mathrm{Ma}$ for 14VT05 and 14VT07 (Fig. 8A and B), respectively.

Sample 14VT10 was collected in the vicinity of the Vermont-New-Hampshire border, from amphibolite facies quartzite beds mapped as the Gile Mountain Formation (Ratcliffe et al., 2011). That sample yielded abundant, clear to amber zircon grains with elliptical, discoidal and elongated columnar prismatic shapes with high length-to-width ratios. 107 analyses out of 130 zircon analyzed grains were kept for age calculations (Fig. 8C). The zircon age distribution for that sample is dominated by a single and prominent age peak at ca. $398 \mathrm{Ma}$ (> 75\% of zircon grains), with small proportion of older grains 
varying from ca. $900 \mathrm{Ma}$ to ca. $2.5 \mathrm{Ga}$ (Fig. 8C). Cathodoluminescence images of this younger zircon population do not show any metamorphic rims (Fig. 9) and their Th/U ratio is $>0.1$, suggesting that this peak is not due to metamorphic overprint or mixed age (Hoskin and Schaltegger, 2003).

Youngest HR-LA-ICP-MS detrital ages. Maximum depositional ages (Figs. 6 to 8) were determined by calculating the weighted mean age of the youngest cluster formed by a coherent group of at least three detrital zircon analyses (Dickinson and Gehrels, 2009), whereas the consistency of a given group of analyses has been evaluated by concordant zircons with low U concentration $(\leq 600 \mathrm{ppm}$, because high $\mathrm{U}$ concentrations usually involve $\mathrm{Pb}$ loss) and similar $\mathrm{U} / \mathrm{Th}$ ratios $( \pm 1)$, (see table 1 ). The maximum depositional age of the Ayers Cliff and Waits River formations, as well as of the Compton and Gile Mountain formations, is better defined on the Vermont side of the sedimentary sequence.

In southern Quebec, sample 14MP70 of the Milan member displays a single Early Devonian age peak, defined by 4 analyses with a weighted mean ${ }^{238} \mathrm{U} /{ }^{206} \mathrm{~Pb}$ age of $418 \pm$ $5 \mathrm{Ma}$ (Fig. 6B). For the Lac-Drolet member, samples 14MP89 and 13MP26 yielded Silurian peak ages defined by 13 and 10 analyses, respectively. Among these, 9 and 3 analyses respectively define two Early Devonian ${ }^{238} \mathrm{U} /{ }^{206} \mathrm{~Pb}$ weighted mean age clusters of $417 \pm 5$ Ma for 14MP89 and $413 \pm 7$ Ma for 13MP26 (Figs. 6D and 7C).

In northern Vermont, sample 14VT05 of the Waits River Formation shows an Early Devonian age peak defined by 22 analyses. Among these analyses, a coherent group of 8 analyses defines a cluster with a weighted mean ${ }^{238} \mathrm{U} /{ }^{206} \mathrm{~Pb}$ age of $406 \pm 9 \mathrm{Ma}$ (Fig. 8A). In sample 14VT10 of the Gile Mountain, among the $75 \%$ of zircons younger 
than 500Ma, 65 grains compose a Devonian age peak. Among them only 25 zircons are concordant and the younger coherent group forming a cluster contains 6 analyses with a weighted mean ${ }^{238} \mathrm{U} /{ }^{206} \mathrm{~Pb}$ age of $401 \pm 6 \mathrm{Ma}$ (Fig. 8C). Apart from these concordant zircons, the others discordant Devonian zircons of sample 14VT10 (yielding ages younger than $390 \mathrm{Ma}$ ) are attributed to $\mathrm{Pb}$ loss, that can be due to fluid circulation along the nearby Monroe Fault or to younger metamorphism, possibly related to the Alleghanian orogeny.

In summary, several analysed samples yielded zircon populations close to sedimentation age. A maximum age of deposition calculated for the base of the sequence (i.e., Ayers Cliff and Waits River formations) is given by the Waits Rivers Formation at $406 \pm 9 \mathrm{Ma}$ (sample 14VT05). In the upper part of the sequence, the youngest detrital zircon population found in southern Quebec is from the Lac-Drolet member, at $413 \pm 7$ Ma (sample 13MP26), but results from northern Vermont suggest that the Gile Mountain Formation is as young as $401 \pm 6 \mathrm{Ma}$ (sample 14VT10). Those three ages, within error range of each other, are in agreement with the generally accepted, uppermost Silurian to Devonian depositional age of the Gaspé Belt.

\section{3. ${ }^{40} \mathrm{Ar} /{ }^{39} \mathrm{Ar}$ results.}

${ }^{40} \mathrm{Ar} /{ }^{39} \mathrm{Ar}$ analyses on single detrital muscovite grains were performed in southern Quebec, on the same set of samples as the $\mathrm{U} / \mathrm{Pb}$ detrital zircon study. In Vermont, greenschist-facies and higher metamorphic grade fully reset the $\mathrm{K}$-Ar isotopic system of detrital mica and inherited ${ }^{40} \mathrm{Ar} /{ }^{39} \mathrm{Ar}$ ages are not preserved.

Ayers Cliff Formation. ${ }^{40} \mathrm{Ar} /{ }^{39} \mathrm{Ar}$ analyses of detrital muscovites of sample 14MP42 (Fig. 10A) from the Ayers Cliff Formation provided a heterogeneous panel of results. Despite 
a strong disturbance (due to ${ }^{40} \mathrm{Ar} *$ loss and/or partial recrystallization) observed in the low- to intermediate-temperature steps that is attributed to Acadian metamorphism, the analysed muscovite grain 14MP42- $\alpha$ yielded a Mesoproterozoic pseudo-plateau (PP) age of $1107 \pm 2.9 \mathrm{Ma}$ in the high-temperature steps (Fig. 10A), which is likely related to a Grenvillian source. Muscovite analysis 14MP42- $\beta$ (Fig. 10A) yielded a staircase-shaped age spectrum with an increase of apparent ages from ca. 417 Ma to ca. $464 \mathrm{Ma}$, which can be attributed to the late Silurian/Early Devonian partial recrystallization of a mica grain that crystallized during the Middle Ordovician, at ca. 465 Ma. Evidence for a late Silurian/Early Devonian event is also detected through the analysis of a muscovite grain from sample 13MP05 (Fig. 10B). It shows a pronounced saddle-shaped age spectrum interpreted as the mixing of two mineral components after partial recrystallization (Alexandrov et al., 2002; Castonguay et al., 2007; Tartese et al., 2011; Tremblay et al., 2011): a former late Silurian/Early Devonian mineral crystallized at ca. $418 \mathrm{Ma}$, which has been disturbed during a Middle Devonian event (at ca. 376Ma), coinciding with the age of regional metamorphism in the CVG trough as defined by Tremblay et al. (2000).

Milan member of the Compton Formation. Micas from the Milan Member of the Compton Formation provided a series of disturbed age spectra (Fig. 11). The two spectra yielded by white micas of sample 14MP70 show distinct PP ages in the high-temperature steps (Fig. 11A), at ca. $448 \mathrm{Ma}(14 \mathrm{MP} 70-\alpha)$ and ca. $433 \mathrm{Ma}$ (14MP70- $\beta$ ). As for sample 14MP89 of the Lac-Drolet member (Fig. 12A, see below), the saddle shape of 14MP70 spectra (Fig. 11A) suggests that these muscovite grains were affected by partial recrystallization (which has been most likely very limited for mica $14 \mathrm{MP} 70 \alpha$ but more 
extensive for 14MP70 $\beta$ ) during a younger event, as suggested by ca. 360-380 Ma apparent ages in the low-temperature steps of both experiments.

Muscovite age spectra of sample 13MP14 (Fig. 11B) unambiguously display a plateau age at ca. $457 \mathrm{Ma}$ for mica $\alpha$ and a maximum age of ca. $460 \mathrm{Ma}$ for mica $\beta$, with a clear perturbation during a younger Ordovician-Silurian event that is marked by a massive ${ }^{40} \mathrm{Ar}^{*}$ degassing peak (cf. mica $\alpha$ ) and PP ages at ca. 442-448 Ma in the low- to intermediate-temperature steps. A possible Middle Devonian disturbance/recrystallization, at ca. $394 \mathrm{Ma}$, is also observed in the low-temperature steps and characterized by a perfectly defined ${ }^{40} \mathrm{Ar} *$ degassing peak (Fig. 11B)

Finally, in sample 13MP15 (Fig. 11C), except for mica $\beta$ experiment, all detrital muscovite grains yielded strongly-disturbed age spectra. Mica 13MP15- $\beta$ age spectrum suggests that it was partly recrystallized during the early Silurian (at ca. $441 \mathrm{Ma}$ ), as attested by its ${ }^{40} \mathrm{Ar} *$ degassing spectrum, after an initial crystallization which probably occurred during the late Ordovician, as indicated by fusion step apparent age at ca. 450 Ma (Fig. 11C). The density probability diagram (Fig. 11D) for apparent ages of all detrital mica grains from sample 13MP15 suggests that the ca. 440-448 Ma disturbance is a key event, as is a series of Late Devonian perturbations (ca. 380 to $365 \mathrm{Ma}$ ) that we attribute to the regional Acadian metamorphism.

Lac-Drolet member of the Compton Formation. As compared to the Milan member, detrital mica grains of samples 14MP89, 14MP57 and 13MP26 from the LacDrolet member highlight a rather similar tectono-thermal history (Fig. 12).

The three analysed detrital mica grains from sample 14MP89 (Fig. 12A) yielded three distinct but coherent age spectra. Two of them allow PP and plateau age 
calculations at 445.5 \pm 1.3 Ma (14MP89- $\chi)$ and 407.7 $\pm 0.7 \mathrm{Ma}(14 \mathrm{MP} 89-\alpha)$. The third age spectrum (14MP89- $\beta$, Fig. 12A) shows a saddle-shape with minimum apparent ages that are concordant with the lowest plateau age of experiment $14 \mathrm{MP} 89-\alpha$, and hightemperature apparent ages that increase up to fusion, thus suggesting that the $\mathrm{K}-\mathrm{Ar}$ isotopic system of this mica grain closed at or before ca. $446 \mathrm{Ma}$ and was partly recrystallized at ca. $408 \mathrm{Ma}$ (Fig. 12A).

The oldest analysed muscovite grains are provided by sample 14MP57 (Fig. 12B), which yielded Middle Ordovician PP and plateau ages at ca. 458 and 459 Ma, respectively.

However, these micas also show evidence of disturbances during the Late Ordovician. These disturbances resulted in partial recrystallization, probably accompanied by the neo-crystallization, as suggested by the analysis of the ${ }^{40} \mathrm{Ar} *$ degassing spectrum for mica $\beta$ experiment (Fig. 12B). The weighted age spectra of mica $\beta$ (Fig. 12B), in which the degassing rate (rather than the absolute degassing amount) is taken into account (e.g. De Putter et al., 2015), clearly illustrates the intermediatetemperature degassing domain of the Late Ordovician (445-443 Ma) and low-temperature domain of the Late Devonian (ca. 366-372 Ma) disturbances. Neo-crystallization of micas during the Late Ordovician is also indicated by a plateau age at ca. $445 \mathrm{Ma}$ for mica 13MP26- $\alpha$ (Fig. 12C) and, to a lesser extent, by mica 14MP57- $\chi$ as well with a PP age at ca. 443 Ma (Fig. 12B). Early Devonian ages at ca. $418 \mathrm{Ma}$ are shown either as a disturbance on mica 14MP57- $\chi$ (Fig. 12B) and as a PP age on mica 13MP26- $\chi$ (417.6 \pm 2.1, Fig. 12C). All age spectra show evidence for weak disturbances in their lowtemperature steps, with 375-to-355 Ma apparent ages. 
In summary, ${ }^{40} \mathrm{Ar} /{ }^{39} \mathrm{Ar}$ analyses of detrital white micas from both the Ayers Cliff and the Compton formations preserve Precambrian and Middle Ordovician to Early Devonian ages, reflecting the metamorphic history of the Laurentia margin and preMiddle Devonian orogenic phases of the Northern Appalachians (Figs. 10, 11D and 12D). Mica grains with Middle Ordovician ages, typical of the Taconian orogeny in southern Quebec, are present. However, most of them show evidence for a younger Late Ordovician-earliest Silurian event, that is highlighted by several grains yielding Late Ordovician and Early Silurian (re)crystallization ages typical of the Salinic orogeny as defined in eastern Maine and adjacent New Brunswick (see discussion below). In addition, some mica grains also preserve evidence for (re)crystallization/disturbance during an Early Devonian event, which can also be attributed to the Salinic orogeny but are more characteristic of metamorphic rocks of the Laurentian margin cropping out west of the CVG trough. Finally, nearly all muscovite grains show more-or-less pronounced Late to Middle Devonian disturbances related to the Acadian orogeny.

\section{Discussion}

The Silurian Salinic orogeny is generally thought of as a compressive tectonic event in the Northern Appalachians (e.g. Dunning et al., 1990; Cawood et al., 1994a; Cawood et al., 1994b; van Staal et al., 1998). However, a period of Silurian extensional faulting, which has been referred to as the Salinic Disturbance in Gaspé Peninsula (e.g. Boucot, 1962; Bourque et al., 1995; 2000), has been recognized in the Quebec Appalachians and corresponds to the formation and/or reactivation of major normal-sense faults such as the Shickshock-Sud fault in Gaspé Peninsula and the Saint-Joseph fault in southern Quebec (Malo et al., 1995; Pinet et al., 1996; Tremblay and Castonguay, 2002; 
Tremblay and Pinet, 2005, 2016; Perrot, 2014). Existing constraints suggests that Gaspé Belt and the CVS deposition was initiated during a post-Taconian marine transgression within broad, graben-like Silurian sedimentary basin(s) (e.g. Hatch and Stanley, 1988; Bourque et al., 1995, 2000; Robinson et al., 1998; Tucker et al., 2001; Tremblay and Pinet, 2005, 2016; McWilliams et al., 2010). Tremblay and Pinet (2005) interpreted the Salinic Disturbance to have occurred during significant crustal extension marked by regional scale normal faulting in the Quebec (and northern Vermont) segment of the Appalachian orogen.

Detrital zircon and mica age spectra of siliciclastic rocks are intimately linked to the tectonic setting of sedimentary basin(s) in which they were deposited (e.g. Cawood et al., 2012). Our geochronological study of the Gaspé Belt and the CVS complements preliminary age data provided by de Souza et al. (2014) in southern Quebec and fills an age data gap in northern Vermont, which can be used to make a link with detrital ages documented by McWilliams et al. (2010). The whole set of geochronological data, therefore, provides a full perspective of detrital age variations in correlative SilurianDevonian rock sequences of southern Quebec and New England, for a strike length of approximately $300 \mathrm{~km}$.

\subsection{Maximum age of deposition}

\section{The Ayers Cliff and Wait Rivers formations.}

A late Lochkovian to early Pragian age (415-410 Ma) of deposition has been suggested for the Ayers Cliff Formation on the basis of Chitinozoan fauna (Lavoie and Asselin, 2004), providing an age constraint for the base of the upper sequence of the Gaspé Belt as defined by Tremblay and Pinet (2016) in southern Quebec. Such timing is 
consistent, within errors, with detrital zircon ages for the Waits River Formation (418 \pm 7 Ma and $415 \pm 2$ Ma) suggested by McWilliams et al. (2010) in southern Vermont, and with the $406 \pm 9$ Ma youngest age population measured during our study (sample 14VT05), this latter result validating the McWilliams et al. (2010) age which is based on a single zircon grain. Those ages indicate that both the Ayers Cliff and Waits River formations, at least their middle and uppermost sections, are Lochkovian to Emsian (Early Devonian), a timing which is also consistent with detrital muscovite ages yielded by the Ayers Cliff Formation.

\section{The Compton and Gile Mountain formations.}

In southern Quebec, fossil plants in the Compton Formation (Hueber et al., 1990; Lavoie and Asselin, 2004) constrain the uppermost part of the Gaspé Belt to late Silurianto-Emsian. De Souza et al., (2014) obtained U-Pb detrital zircon ages that are generally similar to those of this study. However, one of their sample (09MILAN01) yielded a significant proportion (30\%) of Paleozoic ages extending well into the Devonian, with a maximum weighted mean ${ }^{207} \mathrm{~Pb} /{ }^{206} \mathrm{~Pb}$ age of $396 \pm 6 \mathrm{Ma}$ (Emsian-Eifelian). This age is significantly younger and does not overlap with the youngest weighted mean age we obtained for the Milan member, at $418 \pm 5$ Ma (sample 14MP70; see Fig. 5B). For their maximum age calculation, de Souza et al. (2014) used ${ }^{207} \mathrm{~Pb} /{ }^{206} \mathrm{~Pb}$ ratios whereas we used ${ }^{206} \mathrm{~Pb} /{ }^{238} \mathrm{U}$ ratios. It is well-documented that for $\mathrm{U}-\mathrm{Pb}$ isotopic ages younger than $1 \mathrm{Ga}$, ${ }^{206} \mathrm{~Pb} /{ }^{238} \mathrm{U}$ age calculations are more accurate and less sensitive to lead loss than those based on ${ }^{207} \mathrm{~Pb} /{ }^{206} \mathrm{~Pb}$ ratios (e.g. Nemchin and Cawood, 2005; Gehrels et al., 2008). A ${ }^{206} \mathrm{~Pb} /{ }^{238} \mathrm{U}$ age calculation for sample 09MILAN01 yields a maximum weighted mean age of $415 \pm 12 \mathrm{Ma}$, which is more consistent with our youngest detrital ages for the 
Compton Formation (419-to-413 Ma), and with a youngest weighted mean zircon age of $409 \pm 5$ Ma measured by McWilliams et al. (2010) in the correlative Gile Mountain Formation. Moreover, the youngest weighted mean ${ }^{206} \mathrm{~Pb} /{ }^{238} \mathrm{U}$ age of a coherent group of three zircons for the Lac-Drolet member is $413 \pm 7$ Ma (sample 13MP26: Fig. 7D), consistent with our youngest weighted mean ${ }^{206} \mathrm{~Pb} /{ }^{238} \mathrm{U}$ age $(401 \pm 6 \mathrm{Ma})$ for sample 14VT10 of the Gile Mountain Formation (Fig. 8C). All these results suggest a maximum Praguian-Emsian (410-393 Ma) deposition for the Compton and Gile Mountain formations, consistent with detrital muscovite ages in the Compton Formation.

\subsection{Erosional sources for the Quebec-Vermont units.}

\section{Ayers Cliff and Waits River formations}

Detrital zircon provenance - Continuous exposures on both sides of the Canada - US border indicate that the Ayers Cliff and Waits River formations were deposited in a contiguous paleogeographical environment. Moreover, the consistency between the biostratigraphical age of the Ayers Cliff Formation (late Lochkovian-early Praguian) and the maximum age of deposition of the Waits River Formation, as constrained by detrital zircon $(406 \pm 9 \mathrm{Ma})$, indicate that both formations were formed during the same time interval. However, detrital zircon ages distributions in both units do not support a direct correlation between their respective erosional sources (Fig. 13). Detrital zircon ages of the Waits River Formation measured during this study and those obtained by McWilliams et al. (2010) differ from those of the Ayers Cliff Formation. We think that it can be related to variations in the nature of available erosional sources along the strike of the CVG trough. Detrital zircon from the Ayers Cliff Formation, for instance, highlight an important input of Paleo- to Mesoproterozoic ages, and do not show a significant 
proportion of Silurian and Devonian ages as does the Waits River Formation. We suggest that this reflects the nature of erosional sources as currently exposed along the shoulders of the CVG trough and the CVS, especially the higher proportion of Ordovician magmatic arc rocks and late Silurian volcanic rocks in Vermont as compared to southern Quebec, thus accounting for the larger amount of Ordovician and Silurian-Devonian detrital zircon in the CVS.

Mesoproterozoic detrital zircon of the Ayers Cliff and Waits River formations are consistent with derivation from the Grenville and Superior province and/or as recycled material from the Humber zone (Laurentian margin). A possible source of Grenvillian detritus is also represented by the Chain Lakes Massif (CLM), which crops out at the Quebec-Maine border and is interpreted as a Laurentian margin inlier (Gerbi et al., 2006; de Souza and Tremblay, 2010). The metamorphic rocks of the CLM were probably exposed in Ordovician-early Silurian times, as suggested by a ${ }^{40} \mathrm{Ar} /{ }^{39} \mathrm{Ar}$ muscovite age of $466.6 \pm 0.7 \mathrm{Ma}$ (G. Ruffet, unpubl. data. The age spectrum is available in repository) measured in the Twin Bridges facies (Gerbi et al., 2006). The proximity of the CLM thus probably accounts for a larger proportion of Proterozoic detrital ages in the CVG trough, as compared to the CVS. Ediacaran ages (635-542 Ma) are totally absent from samples of the Ayers Cliff Formation but are found in those of the Waits River Formation. Ediacaran detrital zircons are usually attributed to recycled grains from rift-related magmatism of the Laurentian margin (Humber Zone; Cawood and Nemchin, 2001) or from periGondwanan terranes (O'Brien et al., 1996; Macdonald et al., 2014). Incidentally, Macdonald et al. (2014) recently proposed the existence of a peri-Ganderian terrane, just south of the Quebec-Vermont border, which would have been accreted to Laurentia 
during the Taconian orogeny. Moreover, Karabinos et al. (2017) suggested that this periGanderian extended as far east as the Bronson Hill anticlinorium and as far north as the Gaspé Peninsula. Although the occurrence of Ediacaran zircons in the Waits River Formation is consistent with the existence of the Moretown terrane, their total absence in the correlative Ayers Cliff Formation does not support a large regional extension for that terrane.

The occurrence of Ordovician detrital zircon in the Ayers Cliff and Waits River formations is consistent with derivation from the erosion of Taconian magmatic and metamorphic rocks. In Quebec, Ordovician plutonic and volcanic rocks are mainly found in ophiolites and in the Ascot Complex volcanic arc, whereas in New England such erosional sources are multiple, for instance, the Ammoonoosuc volcanic and plutonic sequence of the Bronson Hill arc (469-443 Ma), the Shelburne Falls arc (502-470 Ma, Karabinos and Hepburn, 2001; Aleinikoff et al., 2011), and the Brookfield plutonic series (454-438 Ma; Sevigny and Hanson, 1995).

Variably abundant Silurian- Early Devonian detrital zircon in the Ayers Cliff and Waits River formations can be attributed to several erosional sources. Silurian- Early Devonian (423-418 Ma) magmatic rocks are found in central Vermont in the ca. $419 \mathrm{Ma}$ Braintree Intrusive Complex (Ratcliffe and Aleinikoff, 2000; Black et al., 2004; Ratcliffe et al., 2011) and the ca. 420 Ma Comerford Intrusive Complex (Rankin et al., 2007; Ratcliffe et al., 2011). There are also the upper Silurian- Early Devonian (ca. $418 \mathrm{Ma}$ ) volcanic rocks of the Frontenac and Perry Mountain formations (Moench et al., 1995; van Grootel et al., 1995; Lyons et al., 1997; Dorais et al., 2016) of southern Quebec and New Hampshire, respectively. Upper Silurian-Early Devonian (423-418 Ma) basaltic flows 
found within the Waits River Formation itself (i.e., the Standing Pond Volcanics; (Aleinikoff and Karabinos, 1990; Moench et al., 1995; Lyons et al., 1997; Rankin et al., 2007) could also have been a source of zircons. However, the relative paucity of such detrital zircon ages in the Ayers Cliff Formation can be attributed either to (1) the fact that part of these late Silurian-Early Devonian magmatic rocks (for instance, the Frontenac Formation) were probably submerged during that time period, a hypothesis consistent with the transgressive nature of the Ayers Cliff Formation (e.g. Bourque et al., 1995; 2000), (2) the possibility that the detrital material eroded from these sources did not reach the sedimentary basin(s) due to the paleotopography, and/or (3) the possibility that the corresponding zircons fraction was not recovered in our samples due to size or quality.

Detrital mica provenance $-{ }^{40} \mathrm{Ar} /{ }^{39} \mathrm{Ar}$ detrital mica ages are providing additional information regarding erosional sources for the Ayers Cliff Formation. Mesoproterozoic micas (i.e., 14MP42-a) are consistent with derivation from the Grenville province and/or as recycled material from the internal Humber zone. Two muscovite grains in the Ayers Cliff Formation preserve partial (re)crystallization during a late-Silurian/Early Devonian event, around 417 Ma. Among these two grains, one shows a previous crystallization event during the Middle Ordovician, at ca. 465 Ma (14MP42- $\beta$ ), and the other one (13MP05) shows a younger age of perturbation at ca. 376 Ma that reflects minor Ar loss during the Acadian orogeny. In southern Quebec, Early Devonian ${ }^{40} \mathrm{Ar} /{ }^{39} \mathrm{Ar}$ metamorphic ages (ca. $417 \mathrm{Ma}$ ) are found west (present coordinates) of the CVG trough, within the internal Humber zone (see Castonguay et al., 2007) and are attributed to the exhumation of the metamorphic core of the Laurentian margin during a late Silurian to Early 
Devonian crustal extension event (e.g. Tremblay and Pinet, 2016). East and south of the CVG trough, the Central plutonic belt of New Brunswick exposes a suite of ca. 423-415 Ma plutons (Whalen et al., 1994; Wilson and Kamo, 2016), which also represent a probable source of detrital mica. However, the coexistence of Middle-Ordovician and Lower-Devonian ${ }^{39} \mathrm{Ar} /{ }^{40} \mathrm{Ar}$ ages in the same muscovite grains is also consistent with metamorphic ages found in the Bathurst Supergroup in New Brunswick, an Ordovician volcanic and sedimentary sequence that yielded 477 to 468 Ma detrital white micas which have been affected by three events of deformation/metamorphism attributed to the Salinic orogeny, among which the D2 event yielded 427 to $418 \mathrm{Ma}{ }^{40} \mathrm{Ar} /{ }^{39} \mathrm{Ar}$ ages (Kellett et al., 2017). Finally, east of the CVG trough, the Chain Lakes Massif also has to be considered as a probable source of detrital mica, as an unpublished study (Ruffet, see repository), yielded a muscovite plateau age at $466.6 \pm 0.7 \mathrm{Ma}$ (see above), and disturbed spectra suggesting a disturbance at or younger than ca. $420 \mathrm{Ma}$.

\section{Compton and Gile Mountain formations}

Detrital zircon provenance - As for the Ayers Cliff and Waits River formations, the Compton and Gile Mountain formations crop out continuously across the QuebecVermont border, indicating coeval deposition (see section 4.1) and mostly common erosional sources, which are clearly attested by homogeneous detrital zircon ages distributions in both units (Fig. 13). There are, however, significant variations towards the top of both sequences, although the Lac-Drolet member does not have known stratigraphic equivalent in Vermont.

Most samples from the lower part of the Compton (the Milan member) and Gile Mountain (the Sharon facies) formations show a bimodal age distribution, with broad 
Precambrian and Paleozoic age peaks (Figs. 13and 14). These results are grossly similar to those obtained by de Souza et al. (2014) in the Milan member of southern Quebec and by McWilliams et al. (2010) (their sample \#3 from the Sharon facies) in southern Vermont. In the Lac-Drolet member, all samples, except for 14MP57 which shows an age distribution transitional between the Milan and Lac-Drolet members, yield contrasting results as compared to de Souza et al. (2014) and age distributions that are, however, similar to that of the Royalton facies (McWilliams et al., 2010, their sample \#4).

As for the Ayers Cliff and Waits River formations, the main sources of detrital zircon are (1) Grenvillian basement rocks from the Laurentian margin (Humber zone) and/or the Chain Lakes Massif, characterized by late Mesoproterozoic to Neoproterozoic zircon ages (Gerbi et al., 2006; de Souza and Tremblay, 2010), and (2) magmatic and metamorphic rocks related to the Taconic, Salinic and Acadian orogeneses, characterized by Ordovician, Silurian and Devonian zircon ages (Sevigny and Hanson, 1995; Ratcliffe and Aleinikoff, 2000; Karabinos and Hepburn, 2001; Black et al., 2004; Rankin et al., 2007; Aleinikoff et al., 2011; Ratcliffe et al., 2011, Dorais et al., 2016). The uppermost stratigraphic samples, 14MP89 and 13MP26, of the Lac-Drolet member, and 14VT10 of the Gile Mountain Formation show a significant proportion of Early Devonian detrital zircon which are mostly columnar zircons with high length-to-width ratios and sharp edges. The abundance of feldspathic wacke in the Lac-Drolet member also suggest a drastic change of erosional sources as compared to underlying units and a more significant input of volcanic zircons. We believe that the occurrence of Silurian-Devonian zircons can be attributed to the contribution of Early Devonian volcanic rocks (as preserved, for instance, in the Piscataquis magmatic belt, Bradley and Tucker, 2002), that 
were mostly formed during deposition of the Lac-Drolet member and the uppermost part of Gile Mountain Formation. This interpretation is consistent with the west-directed migration of the Acadian deformational front and foreland basin development from ca. $425 \mathrm{Ma}$ in Maine to ca. $380 \mathrm{Ma}$ in Quebec (see Bradley et al., 2000). The Piscataquis magmatic belt was probably coeval with Early Devonian rhyolites occurring in the Gile Mountain and Littleton formations in Vermont and New Hampshire (ca. 407-409 Ma, i.e. Rankin and Tucker, 2000, 2009; McWilliams et al., 2010).

Contrasting with the Ayers Cliff Formation, but similarly to the Waits River Formation, samples 13MP14 and 13MP15 of the Compton Formation and those of the Gile Mountain Formation show a significant proportion of late Neoproterozoic detrital zircon (Figs. 13and 14). The coexistence of ca. 460 Ma and 620-640 Ma zircons in these rocks can be attributed to the contribution of three distinct westerly sources, (1) the volcanic arc rocks of the Ascot Complex (460 Ma 3 Ma, David et al., 1993), (2) the Neoproterozoic basement and/or rift-related intrusive and volcanic rocks of the Laurentian margin (Humber zone) although the common ages of this rifting event is a little bit younger (615-510, Hodych and Cox, 2007) or 3) to the recycling of western Ganderian-affinity rocks such as the Moretown Formation (Moretown terrane of Macdonald et al., 2014). However, it can also record the recycling of east-derived periGondwanan terranes, such as the Ordovician volcanic-plutonic sequence and Neoproterozoic crystalline basement of the Bronson Hill arc massif (Stanley and Ratcliffe, 1985; Tucker and Robinson, 1990; Moench, 1993; Karabinos et al., 2015). Considering the proximity and the large volume of rocks represented by the Bronson Hill arc, it is here considered as a major source of Late Ordovician to early Silurian detrital 
zircon. If correct, the relatively low abundance (ca. 3\%) of Neoproterozoic zircons is somewhat surprising, although it may be an indication that erosional levels of the Bronson Hill arc did not profoundly reach its Proterozoic basement.

Detrital mica provenance - Ordovician to Devonian sources are well expressed by the ${ }^{40} \mathrm{Ar} /{ }^{39} \mathrm{Ar}$ age data from the Compton/Gile Mountain formations, which highlights three groups of detrital mica ages, (1) ca. 460-455 Ma, (2) ca. 445-440 Ma and (3) ca. 417 and $408 \mathrm{Ma}$.

Middle Ordovician mica ages, ca. 460-455 Ma, are mainly attributed to westerly sources related to the Taconian metamorphic hinterland as preserved in the internal Humber zone (e.g. Tremblay and Pinet, 2016). In southern Quebec, Middle Ordovician white micas are found in the Notre-Dame and Sutton Mountains anticlinoria (Castonguay et al., 2001; 2007), and in metamorphic rocks of the Caldwell Group cropping out in the Bécancour and Carineault structural windows (Whitehead et al., 1995; Tremblay et al., 2011), including the infra-ophiolitic metamorphic sole of the Thetford Mines ophiolite (TMO). Peridotite-hosted granitoids of the TMO and the Rivière-des-Plantes ultramafic complex also preserve ca. 465-460 Ma muscovite ages (Tremblay et al., 2011; de Souza, 2012), whereas Middle Ordovician muscovite ages were also measured in the sole rocks of the Lac-Brompton ophiolite (de Souza, 2012). In the Gaspé Peninsula, white micas that yielded ${ }^{40} \mathrm{Ar} /{ }^{39} \mathrm{Ar}$ Middle Ordovician ages are found in greenschist-grade metasedimentary rocks of the Mount Logan nappe and in the metamorphic sole of the Mont-Albert ophiolite (Pincivy et al., 2003; Malo et al., 2008).

Late Ordovician to early Silurian (ca. 445-440 Ma) white mica sources are found on both sides of the CVG trough. To the west, there is only scarce evidence of 446-435 
Ma metamorphic mica ages preserved in the Green Mountains slice of Vermont (Laird et al., 1984; Sutter et al., 1985; Castonguay et al., 2012). The reason for such scarcity can be attributed to the real paucity of such ages and also to the lack of data and/or to the Acadian metamorphic overprint. East and south of the CVG trough, metamorphic rocks of the Bathurst Supergroup preserve abundant ca. 452 to 437 Ma muscovite ages that have been attributed to a Salinic $\mathrm{D}_{1}$ metamorphic event (van Staal and Barr, 2012; Kellett et al., 2017). The scarcity of Late Ordovician to early Silurian ${ }^{40} \mathrm{Ar} /{ }^{39} \mathrm{Ar}$ ages measured to the west of the CVG trough as compared to their abundance to the east, suggest that the Bathurst Supergroup is likely a major source of Late Ordovician to early Silurian detrital mica.

Early Devonian metamorphic ages (417 and $408 \mathrm{Ma}$ ) are found on both sides of the CVG trough. To the west, the internal Humber zone of southern Quebec and adjacent Vermont preserve abundant metamorphic micas of that age range and have been attributed to late stages of Salinic metamorphism and deformation (Castonguay et al., 2001; 2007; 2012). East and south of the CVG trough, the Bathurst Supergroup preserves evidence for 427-418 Ma and 412-406 Ma metamorphic white micas (e.g. Kellett et al., 2017), further supporting it as a likely source.

A discriminant element between western and eastern provenance can be invoked for late Silurian muscovite ages. Although the Humber zone is considered as a major erosional source, the lack of detrital mica plateau ages of 430-420 Ma in our samples is surprising, especially since such metamorphic ages are quite common in southern Quebec (see Castonguay et al., 2001; 2007; 2012). Only a few individual step ages of ca. 430-420 Ma are highlighted by the density probability diagrams (Fig. 11D and 12D). We think 
that limited evidence of late Silurian-Early Devonian detrital mica can be attributed either to (1) the fact that, due to the late Silurian transgression (Bourque et al., 1995; 2000), most metamorphic rocks sources of the internal Humber zone were submerged during that time, (2) these late Silurian-Early Devonian metamorphic sources were not yet totally exhumed along Laurentia, and/or (3) the corresponding mica fractions were not recovered in our samples.

\subsection{Paleogeographic considerations and tectonic implications for the Quebec-} New England Appalachians

Three composite detrital zircon ages distributions from groups of samples from the same stratigraphic units of the CVG trough are shown in figure 14 and illustrates the upsection increase of Paleozoic (mostly Silurian-Devonian) detrital zircon input into the sedimentary basin relative to the Proterozoic grains. East of the CVG trough, a similar tendency is observed in the late Silurian to Devonian units of the CMB (Fig. 14, Dorais et al., 2009; Bradley and O'Sullivan, 2016). The detrital ${ }^{40} \mathrm{Ar} /{ }^{39} \mathrm{Ar}$ muscovite ages density distribution (Figs. 11D and 12D) of this study shows the same tendency, with an upsection increasing proportion of Silurian-Devonian detrital ages as compared to the Ordovician and Mesoproterozoic ages. Those tendencies indicate a much more important detrital input from Silurian-Devonian erosional sources toward the upper part of the CVG trough, most likely from rock sequences that have were affected by Salinic metamorphism as suggested by abundant metamorphic muscovites of that age range.

In terms of detrital zircon, the most significant characteristics of the CVG trough are the lack of $\mathrm{U}-\mathrm{Pb}$ detrital zircon ages close to the time of deposition in the lowermost samples compared to the increase of Silurian-to-Devonian ages towards the top of the 
sequence (Fig. 8). Detrital zircon data also indicate the existence of compositional variations in the nature of erosional sources along the strike of the CVG trough during deposition of the Ayers Cliff/Waits River formations in latest Silurian to earliest Devonian time (Fig. 13). In contrast, detrital zircon provenances for the Compton and Gile Mountain formations remain mostly the same (Fig. 13). Such variations of erosional sources between the base and the top of the CVG trough probably reflect the progressive west-directed (present coordinates) migration of Ganderian and/or Avalonian terrane accompanied by deformation and continuing exhumation of Laurentia during the early stages of the Acadian orogeny. This allows us to speculate on the tectonic evolution of the CVG trough from late Silurian to Devonian times, and to propose a post-Taconian, pre-Acadian paleotectonic evolution scenario for the Quebec-New England Appalachians (Figs. 15and 16).

Following tectonic convergence between Laurentia and outboard oceanic arc terranes during the Taconian orogeny (Osberg, 1978; Stanley and Ratcliffe, 1985; Robinson et al., 1998; van Staal and Barr, 2012; Tremblay and Pinet, 2016), the Salinic orogeny initiated during the latest Ordovician (448-440 Ma) and culminated in late Silurian (430-422 Ma) by collision between composite Laurentia and Ganderia, which may have been accommodated by west-dipping subduction (e.g. van Staal and Barr, 2012). In southern Quebec and adjacent western New England, Salinic deformation is characterized by a series of hinterland-directed folds and faults and associated low-grade metamorphism mostly developed in the internal Humber zone (see Tremblay and Pinet, 2016 for a review). Based on detrital zircon ages of sedimentary rocks of the Magog Group of the southern Quebec Dunnage zone, Perrot et al. (2017) suggested that the early 
Silurian (435-425 Ma) sedimentation of the uppermost part of the Magog Group (i.e., the Saint-Victor Formation) can be interpreted as syn-Salinic. Consequently, they suggest that the Saint-Victor Formation should be re-assigned to the lowermost part of the Gaspé belt (see also Tremblay and Pinet, 2016). This is the reason why on figure 15, we compare detrital zircon age distributions of the Saint-Victor Formation (i.e., considered as the lowermost part of the Gaspé Belt) and the lowermost stratigraphic units of the CMB (Bradley and O'Sullivan, 2016), two sedimentary sequences that are thus broadly time-equivalent but belong to widely-separated basins. Both sequences are, in fact, quite distinctive in terms of detrital zircon. They both show a significant amount of Silurian zircons, but the Saint-Victor Formation is characterized by a much larger proportion of Proterozoic grains (Fig. 15), which is consistent with a paleogeographic setting involving a limited contribution of westerly sources in the CMB during the early Silurian, and zircon contributions mainly originating from Laurentian terranes in the Gaspé Belt.

In Quebec, the deposition of the Saint-Victor Formation has been followed by a late Silurian event of crustal extension (attributed to slab delamination and/or subduction retreat by Tremblay and Pinet, 2005) and the formation of the CVG trough. Figure 16A shows that during the late Silurian-Early Devonian, a series of normal faults were initiated to form the CVG trough sedimentary basin, marked by discontinuous horizons of conglomerates in the Lac-Lambton and Shaw Mountain formations of Quebec and Vermont, respectively. Proterozoic detrital muscovites and zircons in the base of the sequence (i.e., samples 13MP42, 13MP05 and 14VT05 of the Ayers Cliff and Waits River formations) yielded age results that are in agreement with a westward derivation from the Grenville and Superior provinces and/or from the Humber zone and, 
alternatively, from the Chain Lakes Massif east of the basin. However, a higher proportion of Precambrian zircons in the CVG trough as compared to the CMB (Bradley and O'Sullivan, 2016) is more consistent with the predominance of westward erosional sources. In corollary, a lower amount of detrital Neoproterozoic zircons in the CVG trough as compared to the $\mathrm{CMB}$ reveals the increasing contribution of approaching Ganderian/Avalonian terranes at the onset of the Acadian orogeny (Bradley and O'Sullivan, 2016). The almost total absence of Ordovician to mid-Silurian zircons in our lowermost samples of the CVG trough is noteworthy, considering the abundance of such zircon ages in the Saint-Victor Formation (Perrot et al., 2017). We suggest that it can be related to the fact that, following the deposition of the Magog Group, most proximal late Ordovician to mid-Silurian erosional sources were submerged during the Silurian marine transgression on the Laurentian side of the basin (e.g. Bourque et al., 1995; 2000). Moreover, it can be linked with the CVG trough formation in an extensional setting as suggested by Tremblay and Pinet (2005). In such a context, the only few occurrences of detrital zircon ages close to the depositional age of the CVG trough reflect the erosion of rift-type magmatic rocks, representing only a minor fraction of ages spectra due to the largely mafic composition and low zircon yield of such rock types (e.g. Cawood et al., 2012).

In Pragian to Emsian (410-395Ma; Fig. 16B), detrital age distribution in the uppermost units of the CVG trough becomes much more homogeneous and is similar to zircon age populations of rock units lying at the top of the CMB (see Bradley and O'Sullivan, 2016). The approaching, NW-migrating Avalonia is considered as the main cause of the homogenisation of zircon provenances in southern Quebec and Vermont. We 
believe that this is the result of a transition between an extensional setting and the development of an onlapping, syn-collisional foreland basin formed during the early stages of the Acadian orogeny. The increasing proportion of detrital zircon ages close to the age of sedimentation in the Compton and Gile Mountain formations is consistent with such a tectonic setting transition. The occurrence of abundant Pragian detrital zircon towards the top of the CVG trough can be thus interpreted as a direct consequence of the erosional contribution of Early Devonian magmatic sources as preserved in the Piscataquis magmatic belt and correlative volcanic sequences in southern Quebec and adjacent New England.

\section{Conclusion}

The investigation of the provenance of detrital minerals in orogenic basins such as the CVG trough is a key element to better define the evolution of tectonic plate mosaic of the Northern Appalachians, particularly because the CVG trough was formed and deformed along major plate boundaries between Laurentia and peri-Gondwana terranes.

The youngest detrital zircon populations measured during this study suggest that the base of the sedimentary sequence of the CVG trough (i.e., the Ayers Cliff and Waits River formations) is as young as $406 \pm 9 \mathrm{Ma}$, whereas the uppermost units (i.e., the Compton and Gile Mountain formations) are as young as $401 \pm 6 \mathrm{Ma}$. These youngest ages were obtained in samples from Vermont and are indicative of continuous sedimentation of both the Gaspé Belt and the CVS throughout Emsian. However, only a small number of the analyzed samples yielded detrital zircon populations that can be considered as representative of the true age of sedimentation, suggesting that most proximal early Silurian to Devonian erosional sources were submerged during deposition, 
which can be attributed to a major marine transgression in the Northern Appalachians during the Silurian (Bourque et al., 1995; 2000). It can also reflect the scarcity of zircons formed during deposition and the early stages of Silurian basin development in this part of the orogenic belt. Overall, the detrital $\mathrm{U}-\mathrm{Pb}$ zircon ages distribution of the CVG trough reflects a transition between slab retreat/delamination-related extensional during latestages of the Salinic orogeny to syn-collisional tectonism and Acadian foreland basin development.

Contrasting zircon age distributions between the Ayers Cliff and Waits River formations are due to variations in the nature of erosional sources along the strike of the basin and/or to the fact that detrital minerals eroded from a given source did not reach the sedimentary basin(s) due to a specific paleogeographic environment. Similar detrital zircon ages distributions for the Compton and Gile Mountain formations, however, indicate the homogenization of erosional sources, which we attribute to approaching Avalonian terranes (including Ganderia) during the Early Devonian.

Detrital muscovite ${ }^{40} \mathrm{Ar} /{ }^{39} \mathrm{Ar}$ ages in the $\mathrm{CVG}$ trough in southern Quebec, highlight the contribution of erosional sources that record multiple magmatic and metamorphic events, indicating the contribution of crustal sources that experienced Grenvillian, Taconian and Salinic metamorphism. In southern Quebec, thermal disturbances in low-temperature steps of most white mica grains record evidence for partial recrystallization/neo-crystallisation and re-opening of the K-Ar system during the Acadian orogeny. Our data also highlight the presence of Late Ordovician to early Silurian (ca. 445-440 Ma) detrital white micas. Such ages are not well documented in 
metamorphic rocks located west of the Gaspé Belt so it represents a missing part of the detrital metamorphic record that should be investigated in future studies.

\section{Acknowledgement}

This contribution is part of the first author's Ph. D. thesis at the Université du Québec à Montreal (UQAM). We sincerely thank André Poirier for the supervision in the HR-LAICP-MS laboratory. J. Kim is thanked for his field guidance in northern Vermont, and J. Falardeau and M. Vincent-Couture for their assistance during fieldwork and sampling. David Chew, Greg Walsh and Alex Zagorevsky are sincerely thanked for helpful and constructive comments. This study was supported by the Natural Sciences and Engineering Research Council of Canada (NSERC) through an operating grant (PG105669) to A. Tremblay. M. Perrot benefited of additional funding from Geotop graduate student grants in 2015, 2016 and 2017.

\section{References}

Aleinikoff, J. N., and Karabinos, P., 1990, Zircon U-Pb data for the Moretown and Barnard Volcanic Members of the Missisquoi Formation and a dike cutting the Standing Pond volcanics, southeastern Vermont, in Slack, J. F., ed., Summary results of the Glens Falls CUSMAP Project, New York, Vermont, and New Hampshire, Volume 1887, US Geological Survey Bulletin p. D1-D10.

Aleinikoff, J. N., Ratcliffe, N. M., and Walsh, G. J., 2011, Provisional zircon and monazite uranium-lead geochronology for selected rocks from Vermont: US Geological Survey, 2011-1309, 46 p.

Alexandrov, P., Ruffet, G., and Cheilletz, A., 2002, Muscovite recrystallization and saddle-shaped $40 \mathrm{Ar} / 39 \mathrm{Ar}$ age spectra: example from the Blond granite (Massif Central, France): Geochimica et Cosmochimica Acta, v. 66, no. 10, p. 1793-1807.

Armstrong, T., Tracy, R., and Hames, W., 1992, Contrasting styles of Taconian, eastern Acadian and western Acadian metamorphism, central and western New England: Journal of Metamorphic Geology, v. 10, no. 3, p. 415-426.

Armstrong, T., Walsh, G., and Spear, F., 1997, A transect across the Connecticut valley sequence in east-central Vermont, in Grover, T. W., Mango, H.N., and Hasenohr, 
E.J. , ed., New England Intercollegiate Geological Conference, Volume Guidebook to field trips in Vermont and adjacent New Hampshire and New York: 89th Annual Meeting, Castleton, Vermont, p. A6-1-56.

Arth, J. G., and Ayuso, R. A., 1997, The Northeast Kingdom batholith, Vermont: Geochronology and $\mathrm{Nd}, \mathrm{O}, \mathrm{Pb}$, and $\mathrm{Sr}$ isotopic constraints on the origin of Acadian granitic rocks. In : The Nature of Magmatism in the Appalachian Orogen eds Sinha, A. K., Whalen, J.B. and Hogan, J. P. : Geological Society of America Memoirs, v. 191, p. 1-18.

Asselin, E., 2001, Résultats de l'analyse palynologique effectuée sur une série d'échantillons prélevés dans les successions Cambro-Ordoviciennes et SiluroDévoniennes du Québec: Internal Geological Survey of Canada report, 4 p.

-, 2002, Rapport préliminaire sur les résultats palynologiques obtenus pour des séries d'échantillons provenant du Siluro-Dévoniens de l'Estrie et de la Beauce du sud du Québec: Internal Geological Survey of Canada report, 4 p.

Black, L. P., Kamo, S. L., Allen, C. M., Davis, D. W., Aleinikoff, J. N., Valley, J. W., Mundil, R., Campbell, I. H., Korsch, R. J., and Williams, I. S., 2004, Improved $206 \mathrm{~Pb} / 238 \mathrm{U}$ microprobe geochronology by the monitoring of a trace-elementrelated matrix effect; SHRIMP, ID-TIMS, ELA-ICP-MS and oxygen isotope documentation for a series of zircon standards: Chemical Geology, v. 205, no. 12, p. 115-140.

Boucot, A. J., 1962, Appalachian Siluro-Devonian, Some aspects of the Variscan fold belt: Manchester, United Kingdom, Manchester University Press, 9th InterUniversity Geological Congress, p. 155-163.

Bourque, P.-A., Malo, M., and Kirkwood, D., 2000, Paleogeography and tectonosedimentary history at the margin of Laurentia during Silurian to earliest Devonian time: The Gaspé Belt, Québec: Geological Society of America Bulletin, v. 112, no. 1, p. 4-20.

Bourque, P., Brisebois, D., and Malo, M., 1995, Gaspé belt: Geology of the AppalachianCaledonian Orogen in Canada and Greenland. Edited by H. Williams. Geological Survey of Canada, Geology of Canada, no. 6, p. 316-351.

Bradley, D., and Tucker, R., 2002, Emsian Synorogenic Paleogeography of the Maine Appalachians: The Journal of Geology, v. 110, no. 4, p. 483-492.

Bradley, D. C., 1983, Tectonics of the Acadian orogeny in New England and adjacent Canada: The Journal of Geology, p. 381-400.

Bradley, D. C., and O'Sullivan, P., 2016, Detrital zircon geochronology of pre - and syn - collisional strata, Acadian orogen, Maine Appalachians: Basin Research, p. $1-20$.

Bradley, D. C., Tucker, R. D., Lux, D. R., Harris, A. G., and McGregor, D. C., 2000, Migration of the Acadian orogen and foreland basin across the northern Appalachians of Maine and adjacent areas: US Geological Survey, no. 1615, 1-49 p.

Cady, W. M., 1950, Fossil cup corals from the metamorphic rocks of central Vermont: American Journal of Science, v. 248, no. 7, p. 488-497.

Castonguay, S., Kim, J., Thompson, P. J., Gale, M. H., Joyce, N., Laird, J., and Doolan, B. L., 2012, Timing of tectonometamorphism across the Green Mountain anticlinorium, northern Vermont Appalachians: 40Ar/39Ar data and correlations 
with southern Quebec: Geological Society of America Bulletin, v. 124, no. 3-4, p. 352-367.

Castonguay, S., Ruffet, G., and Tremblay, A., 2007, Dating polyphase deformation across low-grade metamorphic belts: An example based on 40Ar/39Ar muscovite age constraints from the southern Quebec Appalachians, Canada: Geological Society of America Bulletin, v. 119, no. 7-8, p. 978-992.

Castonguay, S., Ruffet, G., Tremblay, A., and Féraud, G., 2001, Tectonometamorphic evolution of the southern Québec Appalachians: 40Ar/39Ar evidence for Middle Ordovician crustal thickening and Silurian-Early Devonian exhumation of the internal Humber zone: Geological Society of America Bulletin, v. 113, no. 1, p. 144-160.

Cawood, P., Dunning, G., van Gool, J., and Lux, D., 1994a, Collisional tectonics along the Appalachian margin of Laurentia: constraints from Corner Brook Lake and Baie Verte: Atlantic Geology, v. 30, no. 2, p. 162b-163.

Cawood, P. A., Dunning, G. R., Lux, D., and van Gool, J. A., 1994b, Timing of peak metamorphism and deformation along the Appalachian margin of Laurentia in Newfoundland: Silurian, not Ordovician: Geology, v. 22, no. 5, p. 399-402.

Cawood, P. A., Hawkesworth, C., and Dhuime, B., 2012, Detrital zircon record and tectonic setting: Geology, v. 40, no. 10, p. 875-878.

Cawood, P. A., and Nemchin, A. A., 2001, Paleogeographic development of the east Laurentian margin: Constraints from $\mathrm{U}-\mathrm{Pb}$ dating of detrital zircons in the Newfoundland Appalachians: Geological Society of America Bulletin, v. 113, no. 9, p. 1234-1246.

Cheilletz, A., Ruffet, G., Marignac, C., Kolli, O., Gasquet, D., Féraud, G., and Bouillin, J., 1999, 40Ar/39Ar dating of shear zones in the Variscan basement of Greater Kabylia (Algeria). Evidence of an Eo-Alpine event at 128 Ma (HauterivianBarremian boundary): geodynamic consequences: Tectonophysics, v. 306, no. 1, p. $97-116$.

David, J., Marquis, R., and Tremblay, A., 1993, U-Pb geochronology of the Dunnage zone in the southern Québec Appalachians, Geological Society of America Abstract with programs, Volume v. 25, p. A-485.

De Putter, T., Ruffet, G., Yans, J., and Mees, F., 2015, The age of supergene manganese deposits in Katanga and its implications for the Neogene evolution of the African Great Lakes Region: Ore Geology Reviews, v. 71, p. 350-362.

de Souza, S., 2012, Évolution Tectonostratigraphique du domaine océanique des Appalaches du sud du Québec dans son contexte péri-Laurentien [PhD: Université du Québec à Montréal, $191 \mathrm{p}$.

de Souza, S., and Tremblay, A., 2010, The Rivière-des-Plante ultramafic Complex, southern Québec: Stratigraphy, structure, and implications for the Chain Lakes massif: Geological Society of America Memoirs, v. 206, p. 123-139.

de Souza, S., Tremblay, A., and Ruffet, G., 2014, Taconian orogenesis, sedimentation and magmatism in the southern Quebec-northern Vermont Appalachians: Stratigraphic and detrital mineral record of Iapetan suturing: American journal of science, v. 314, no. 7, p. 1065-1103. 
Desjardins, C., 1994, Pétrologie et géochimie des roches volcaniques des formations de Frontenac et de Clinton, Lac Mégantic [Mémoire de maîtrise: Université Laval, Québec.

Dickinson, W. R., and Gehrels, G. E., 2009, Use of U-Pb ages of detrital zircons to infer maximum depositional ages of strata: a test against a Colorado Plateau Mesozoic database: Earth and Planetary Science Letters, v. 288, no. 1, p. 115-125.

Doll, C. G., Cady, W. M., Thompson Jr, J. B., and Billings, M. P., 1961, Centennial geologic map of Vermont, Vermont Geol Survey, scale 250,000.

Dorais, M. J., Markert, K., and Marvinney, R. G., 2016, What is the age of the Frontenac Formation, northern New Hampshire and western Maine?, Geological Society of America Abstracts with Programs., Volume 48.

Dorais, M. J., Marvinney, R. G., and Markert, K., 2017, The age, petrogeneis and tectonic significance of the Frontenac Formation basalts, northern New Hampshire and western Maine: American Journal of Science, v. 317, no. 9, p. 990-1018.

Dorais, M. J., Wintsch, R. P., Nelson, W. R., and Tubrett, M., 2009, Insights into the Acadian orogeny, New England Appalachians: a provenance study of the Carrabassett and Kittery formations, Maine: Atlantic Geology, v. 45, p. 50-71.

Dunning, G., O'brien, S., Colman-Sadd, S., Blackwood, R., Dickson, W., O'neill, P., and Krogh, T., 1990, Silurian orogeny in the Newfoundland Appalachians: The Journal of Geology, p. 895-913.

Elbert, D. C., Harris, A. G., and Denkler, K. E., 1988, Earliest Devonian conodonts from marbles of the Fitch Formation, Bernardston Nappe, north-central Massachusetts: American Journal of Science, v. 288, no. 7, p. 684-700.

Gehrels, G. E., Blakey, R., Karlstrom, K. E., Timmons, J. M., Dickinson, B., and Pecha, M., 2011, Detrital zircon U-Pb geochronology of Paleozoic strata in the Grand Canyon, Arizona: Lithosphere, v. 3, no. 3, p. 183-200.

Gehrels, G. E., Valencia, V. A., and Ruiz, J., 2008, Enhanced precision, accuracy, efficiency, and spatial resolution of $\mathrm{U}-\mathrm{Pb}$ ages by laser ablation multicollector - inductively coupled plasma - mass spectrometry: Geochemistry, Geophysics, Geosystems, v. 9, no. 3, p. 1-13.

Gerbi, C., Johnson, S., and Aleinikoff, J., 2006, Origin and orogenic role of the Chain Lakes massif, Maine and Quebec: Canadian Journal of Earth Sciences, v. 43, no. 3, p. 339-366.

Growdon, M. L., Kunk, M. J., Wintsch, R. P., and Walsh, G. J., 2013, Telescoping metamorphic isograds: Evidence from 40Ar/39Ar dating in the Orange-Milford belt, southern Connecticut: American Journal of Science, v. 313, no. 10, p. 10171053.

Hames, W. E., Tracy, R. J., Ratcliffe, N. M., and Sutter, J. F., 1991, Petrologic, structural, and geochronologic characteristics of the Acadian metamorphic overprint on the Taconide zone in part of southwestern New England: American Journal of Science, v. 291, no. 9, p. 887-913.

Hatch, N., St-Julien, P., and Beland, J., 1982, Taconian line in western New England and its implications to Paleozoic tectonic history: Geological Association of Canada, Special Paper, v. 24, p. 67-85. 
Hatch, N. L., 1988a, New evidence for faulting along the" Monroe Line", eastern Vermont and westernmost New Hampshire: American Journal of Science, v. 288, no. 1, p. 1-18.

-, 1988b, Some revisions to the stratigraphy and structure of the Connecticut Valley trough, eastern Vermont: American Journal of Science, v. 288, no. 10, p. 10411059.

Hatch, N. L., and Stanley, R. S., 1988, Post-Taconian structural geology of the RoweHawley zone and the Connecticut Valley belt west of the Mesozoic basins: US Geological survey professional paper; 1366-C.

Hibbard, J., Van Staal, C., Rankin, D., and Williams, H., 2006, Lithotectonic map of the Appalachian Orogen: Geological Survey of Canada 2 sheets, scale 1:1,500,000.

Hodych, J. P., and Cox, R. A., 2007, Ediacaran U-Pb zircon dates for the Lac Matapédia and Mt. St.-Anselme basalts of the Quebec Appalachians: support for a long-lived mantle plume during the rifting phase of Iapetus opening: Canadian Journal of Earth Sciences, v. 44, no. 4, p. 565-581.

Horstwood, M. S., Košler, J., Gehrels, G., Jackson, S. E., McLean, N. M., Paton, C., Pearson, N. J., Sircombe, K., Sylvester, P., and Vermeesch, P., 2016, Community - Derived Standards for LA - ICP-MS U - (Th - ) Pb Geochronology - Uncertainty Propagation, Age Interpretation and Data Reporting: Geostandards and Geoanalytical Research, v. 40, no. 3, p. 311-332.

Hoskin, P. W., and Schaltegger, U., 2003, The composition of zircon and igneous and metamorphic petrogenesis: Reviews in mineralogy and geochemistry, v. 53, no. 1, p. 27-62.

Hueber, F. M., Bothner, W. A., Hatch, N. L., Finney, S. C., and Aleinikoff, J. N., 1990, Devonian plants from southern Quebec and northern New Hampshire and the age of the Connecticut Valley trough: American Journal of Science, v. 290, no. 4, p. 360-395.

Karabinos, P., 1998, Tectonic and stratigraphic development of the Connecticut Valley Trough in the New England Appalachians, Geological Society of America Abstracts with Programs, Volume 30, p. 191.

Karabinos, P., Crowley, J., and Macdonald, F., 2015, Detrital zircon constraints on the age of the Poplar Mountain gneiss in the Pelham dome: implications for the tectonic setting of the Bronson Hill arc, Geological Society of America Abstracts with Programs, Volume 47, p. 41.

Karabinos, P., and Hepburn, J., 2001, Geochronology and geochemistry of the Shelburne Falls arc: the Taconic Orogeny in western New England, Guidebook to Geological Field Trips in New England: Boulder, Colorado, Geological Society of America, p. H1-H20.

Karabinos, P., Macdonald, F. A., and Crowley, J. L., 2017, Bridging the gap between the foreland and hinterland I: Geochronology and plate tectonic geometry of Ordovician magmatism and terrane accretion on the Laurentian margin of New England: American Journal of Science, v. 317, no. 5, p. 515-554.

Kellett, D. A., van Staal, C., Wilson, R. A., and Rogers, N., 2017, The age of salinic deformation constrained by 40Ar/39Ar dating of multiple cleavage domains: Bathurst Supergroup, New Brunswick Appalachians: American Journal of Science, v. 317, no. 3, p. 338-368. 
Krogh, T., 1973, A low-contamination method for hydrothermal decomposition of zircon and extraction of $\mathrm{U}$ and $\mathrm{Pb}$ for isotopic age determinations: Geochimica et cosmochimica acta, v. 37, no. 3, p. 485-494.

Lafrance, B., 1995, Nouvelles données stratigraphiques et structurales dans la partie surest du synclinorium de Connecticut Valley-Gaspé, Appalaches du Sud du Québec [Maitrise en Sciences de la Terre]: Université du Québec, INRS-Géoressiources, $58 \mathrm{p}$.

Lagor, S. W., 2016, The relationship between magmatism and deformation during the Acadian orogeny: a case study from eastern-central Vermont [Master of Sciences]: University of Vermont, $178 \mathrm{p}$.

Laird, J., Lanphere, M. A., and Albee, A. L., 1984, Distribution of Ordovician and Devonian metamorphism in mafic and pelitic schists from northern Vermont: American Journal of Science, v. 284, no. 4-5, p. 376-413.

Lavoie, D., 2004, The Lower Devonian Compton Formation in southern Quebec: from delta front to pro-delta sedimentation: Canadian Journal of Earth Sciences, v. 41, no. 5 , p. 571-585.

Lavoie, D., and Asselin, E., 2004, A new stratigraphic framework for the Gaspé Belt in southern Quebec: implications for the pre-Acadian Appalachians of eastern Canada: Canadian Journal of Earth Sciences, v. 41, no. 5, p. 507-525.

Lavoie, D., and Bourque, P.-A., 1992, Stratigraphy, paleoenvironmental evolution and regional significance of the Silurian Lake Aylmer-Lake Saint-François belt, Eastern Townships, Québc: Atlantic Geology, v. 28, no. 3, p. 243-255.

Lavoie, D., and Tremblay, A., 1993, The Silurian-Devonian succession of the Eastern Townships, southern Québec Appalachians: Paleogeographic evolution and comparison with the Gaspé Belt, Geological Society of America, Annual Meeting, Program with abstracts, Volume 25.

Lebel, D., and Tremblay, A., 1993, Géologie de la région de Lac-Mégantic (Estrie): Ministère de l'Énergie et des Ressources du Québec, DV 93-04, 1 p.

Ludwig, K. R., 2012, Isoplot 3.75, A Geochronological Toolkit for Microsoft Excel Berkeley Geochronology Center Special Publication No. 5, University of California at Berkeley.

Lyons, J., Bothner, W., Moench, R., and Thompson Jr, J., 1997, Bedrock geologic map of New Hampshire, U.S. Geological Survey, scale 1:250,000.

Macdonald, F., Ryan-Davis, J., Coish, R., Crowley, J., and Karabinos, P., 2014, A newly identified Gondwanan terrane in the northern Appalachian Mountains: Implications for the Taconic orogeny and closure of the Iapetus Ocean: Geology, v. 42, no. 6, p. 539-542.

Malo, M., Ruffet, G., Pincivy, A., and Tremblay, A., 2008, A 40Ar/39Ar study of oceanic and continental deformation processes during an oblique collision: Taconian orogeny in the Quebec reentrant of the Canadian Appalachians: Tectonics, v. 27, no. 4, p. 1-29.

Malo, M., Tremblay, A., Kirkwood, D., and Cousineau, P., 1995, Along - strike Acadian structural variations in the Québec Appalachians: Consequence of a collision along an irregular margin: Tectonics, v. 14, no. 6, p. 1327-1338. 
Mattinson, J. M., 2005, $\mathrm{Pb}$ chemical abrasion (“CA-TIMS") method: combined annealing and multi-step partial dissolution analysis for improved precision and accuracy of zircon ages: Chemical Geology, v. 220, no. 1-2, p. 47-66.

McWilliams, C. K., Walsh, G. J., and Wintsch, R. P., 2010, Silurian-Devonian age and tectonic setting of the Connecticut Valley-Gaspé trough in Vermont based on U$\mathrm{Pb}$ SHRIMP analyses of detrital zircons: American Journal of Science, v. 310, no. 5, p. 325-363.

Moench, R., 1993, Highlights of metamorphic stratigraphy and tectonics in western Maine to northeastern Vermont: Field trip guidebook for the northeastern United States, p. 01-32.

Moench, R. H., and Aleinikoff, J. N., 2003, Stratigraphy, geochronology, and accretionary terrane settings of two Bronson Hill arc sequences, northern New England: Physics and Chemistry of the Earth, Parts A/B/C, v. 28, no. 1, p. 113160.

Moench, R. H., Boone, G., Bothner, W., Boudette, E., Hatch Jr, N., Hussey III, A., and Marvinney, R., 1995, Geologic Map of the Sherbrooke-Lewiston Area, Maine, New Hampshire, and Vermont, United States, and Quebec, Canada, US Geological Survey, Map I-1898D, scale 1:250,000.

Nemchin, A. A., and Cawood, P. A., 2005, Discordance of the U-Pb system in detrital zircons: implication for provenance studies of sedimentary rocks: Sedimentary Geology, v. 182, no. 1, p. 143-162.

O'Brien, S., O'Brien, B., Dunning, G., and Tucker, R., 1996, Late Neoproterozoic Avalonian and related peri-Gondwanan rocks of the Newfoundland Appalachians: Special papers-Geological Society of America, p. 9-28.

Osberg, P. H., 1978, Synthesis of the geology of the northeastern Appalachians, USA: IGCP project, v. 27, p. 78-13.

Osberg, P. H., Tull, J.F., Robinson, P., Hon, R., Butler, J. R. , 1989, The Acadian orogen, in America, T. G. S. o., ed., The Appalachian-Ouachita orogen in theUnited States Volume F-2, R.D. Hatcher, Jr, W. A. Thomas and G. W. Viele, p. 179-232.

Paton, C., Hellstrom, J., Paul, B., Woodhead, J., and Hergt, J., 2011, Iolite: Freeware for the visualisation and processing of mass spectrometric data: Journal of Analytical Atomic Spectrometry, v. 26, no. 12, p. 2508-2518.

Perrot, M., 2014, Étude structurale et microstructurale de la faille St-Joseph et de la ligne Baie Verte-Brompton dans les Appalaches du sud du Québec [M.Sc.: Université du Québec à Montréal, $77 \mathrm{p}$.

Perrot, M., Tremblay, A., and David, J., 2017, Detrital zircon U-Pb geochronology of the Magog Group, southern Québec - Stratigraphic and tectonic implication for the Québec Appalachians: American Journal of Science, v. 317, p. 1049-1094.

Pincivy, A., Malo, M., Ruffet, G., Tremblay, A., and Sacks, P. E., 2003, Regional metamorphism of the Appalachian Humber zone of Gaspé Peninsula: 40Ar/39Ar evidence for crustal thickening during the Taconian orogeny: Canadian Journal of Earth Sciences, v. 40, no. 2, p. 301-315.

Pinet, N., 2013, Gaspé Belt subsurface geometry in the northern Québec Appalachians as revealed by an integrated geophysical and geological study: 2-Seismic interpretation and potential field modelling results: Tectonophysics, v. 588, p. 100-117. 
Pinet, N., Tremblay, A., and Sosson, M., 1996, Extension versus shortening models for hinterland-directed motions in the southern Québec Appalachians: Tectonophysics, v. 267, no. 1, p. 239-256.

Rankin, D., Coish, R., Tucker, R., Peng, Z., Wilson, S., and Rouff, A., 2007, Silurian extension in the Upper Connecticut Valley, United States and the origin of middle Paleozoic basins in the Quebec embayment: American Journal of Science, v. 307, no. 1, p. 216-264.

Rankin, D., and Tucker, R., 2000, Monroe fault truncated by Mesozoic (?) Connecticut Valley rift system at Bradford, VT: relationship to the Piermont allochthon, Geological Society of America Abstracts with Programs, Volume 31, p. A-67.

-, 2009, Bronson Hill and Connecticut Valley sequences in the Stone Mountain area, Northeast Kingdom, Vermont, Guidebook for Field Trips in the Northeast Kingdom of Vermont and Adjacent Regions: New England Intercollegiate Geological Conference, 101st Annual Meeting: Lyndonville, Vermont, Lyndon State College, p. 187-198.

Rankin, D. W., Tucker, R. D., and Amelin, Y., 2013, Reevaluation of the PiermontFrontenac allochthon in the Upper Connecticut Valley: Restoration of a coherent Boundary Mountains-Bronson Hill stratigraphic sequence: Geological Society of America Bulletin, v. 125, no. 5-6, p. 998-1024.

Ratcliffe, N. M., and Aleinikoff, J. N., 2000, Silurian age of the Braintree Complex VT: bearing on the age of the Cram Hill and Shaw Mountain Formations: : Geological Society of America, Abstracts with Programs, v. 32, no. 1, p. 68.

Ratcliffe, N. M., Stanley, R. S., Gale, M. H., Thompson, P. J., and Walsh, G. J., 2011, Bedrock geologic map of Vermont, US Geological Survey Scientific Investigations, Map 3184, 3 sheets, scale 1:100,000.

Robinson, P., Tucker, R. D., Bradley, D., Berry IV, H. N., and Osberg, P. H., 1998, Paleozoic orogens in New England, USA: GFF, v. 120, no. 2, p. 119-148.

Ruffet, G., Féraud, G., and Amouric, M., 1991, Comparison of 40Ar-39Ar conventional and laser dating of biotites from the North Trégor Batholith: Geochimica et Cosmochimica Acta, v. 55, no. 6, p. 1675-1688.

Sevigny, J., and Hanson, G., 1995, Late-Taconian and pre-Acadian history of the New England Appalachians of southwestern Connecticut: Geological Society of America Bulletin, v. 107, no. 4, p. 487-498.

Simonetti, A., and Doig, R., 1990, U-Pb and Rb-Sr geochronology of Acadian plutonism in the Dunnage zone of the southeastern Quebec Appalachians: Canadian Journal of Earth Sciences, v. 27, no. 7, p. 881-892.

Slack, J., 1994, Geochemical constraints on the evolution of the Connecticut Valley Trough, east-central Vermont, Geological Society of America Abstracts with Programs, Volume 26, p. 73.

Spencer, C. J., Kirkland, C. L., and Taylor, R. J., 2016, Strategies towards statistically robust interpretations of in situ $\mathrm{U}-\mathrm{Pb}$ zircon geochronology: Geoscience Frontiers, v. 7, no. 4, p. 581-589.

Stanley, R. S., and Ratcliffe, N. M., 1985, Tectonic synthesis of the Taconian orogeny in western New England: Geological Society of America Bulletin, v. 96, no. 10, p. 1227-1250. 
Sutter, J. F., Ratcliffe, N. M., and Mukasa, S. B., 1985, 40Ar/39Ar and K-Ar data bearing on the metamorphic and tectonic history of western New England: Geological Society of America Bulletin, v. 96, no. 1, p. 123-136.

Tartese, R., Ruffet, G., Poujol, M., Boulvais, P., and Ireland, T. R., 2011, Simultaneous resetting of the muscovite $\mathrm{K}$ - Ar and monazite $\mathrm{U}-\mathrm{Pb}$ geochronometers: a story of fluids: Terra Nova, v. 23, no. 6, p. 390-398.

Tremblay, A., and Castonguay, S., 2002, Structural evolution of the Laurentian margin revisited (southern Quebec Appalachians): Implications for the Salinian orogeny and successor basins: Geology, v. 30, no. 1, p. 79-82.

Tremblay, A., and Pinet, N., 2005, Diachronous supracrustal extension in an intraplate setting and the origin of the Connecticut Valley-Gaspé and Merrimack troughs, northern Appalachians: Geological Magazine, v. 142, no. 1, p. 7-22.

-, 2016, Late Neoproterozoic to Permian tectonic evolution of the Quebec Appalachians, Canada: Earth-Science Reviews, v. 160, p. 131-170.

Tremblay, A., Ruffet, G., and Bédard, J. H., 2011, Obduction of Tethyan-type ophiolites - A case-study from the Thetford-Mines ophiolitic Complex, Quebec Appalachians, Canada: Lithos, v. 125, no. 1, p. 10-26.

Tremblay, A., Ruffet, G., and Castonguay, S., 2000, Acadian metamorphism in the Dunnage zone of southern Québec, northern Appalachians: 40Ar/39Ar evidence for collision diachronism: Geological Society of America Bulletin, v. 112, no. 1, p. 136-146.

Tucker, R., Osberg, P., and Berry, H., 2001, The geology of a part of Acadia and the nature of the Acadian orogeny across central and eastern Maine: American Journal of Science, v. 301, no. 3, p. 205-260.

Tucker, R. D., and Robinson, P., 1990, Age and setting of the Bronson Hill magmatic arc: A re-evaluation based on U-Pb zircon ages in southern New England: Geological Society of America Bulletin, v. 102, no. 10, p. 1404-1419.

van Grootel, G., Tremblay, A., Soufiane, A., Achab, A., and Marquis, R., 1995, Analyse micropaléontologique du synclinorium de Connecticut Valley-Gaspé dans le sud du Québec: étude préliminaire: Ministère des ressources naturelles, MB 95-26, 35 p.

van Staal, C., Dewey, J., Mac Niocaill, C., and McKerrow, W., 1998, The CambrianSilurian tectonic evolution of the northern Appalachians and British Caledonides: history of a complex, west and southwest Pacific-type segment of Iapetus: Geological Society, London, Special Publications, v. 143, no. 1, p. 197-242.

van Staal, C. R., and Barr, S. M., 2012, Lithospheric architecture and tectonic evolution of the Canadian Appalachians, Tectonic Styles in Canada Revisited: the Lithoprobe perspective.: Geological Association of Canada, Special Paper 49, p. 41-95.

van Staal, C. R., Chew, D. M., Zagorevski, A., McNicoll, V., Hibbard, J., Skulski, T., Castonguay, S., Escayola, M. P., and Sylvester, P. J., 2013, Evidence of Late Ediacaran hyperextension of the Laurentian Iapetan margin in the Birchy Complex, Baie Verte Peninsula, northwest Newfoundland: Implications for the opening of Iapetus, formation of peri-Laurentian microcontinents and TaconicGrampian orogenesis: Geoscience Canada, v. 40, no. 2, p. 94-117. 
Waldron, J. W., Schofield, D. I., and Murphy, J. B., 2018, Diachronous Paleozoic accretion of peri-Gondwanan terranes at the Laurentian margin: Geological Society, London, Special Publications, v. 470, p. SP470. 411.

Waldron, J. W., and van Staal, C. R., 2001, Taconian orogeny and the accretion of the Dashwoods block: A peri-Laurentian microcontinent in the Iapetus Ocean: Geology, v. 29, no. 9, p. 811-814.

Walsh, G. J., Kim, J., Gale, M. H., and King, S. M., 2010, Bedrock geologic map of the Montpelier and Barre West quadrangles, Washington and Orange counties, Vermont, US Geological Survey Scientific investigation, Map 3111, 1 sheet, 36 p. text, scale 1:24000.

Walsh, G. J., Valley, P. M., and Sicard, K. R., 2012, A transect through the base of the Bronson Hill anticlinorium in western New Hampshire, in Thompson, P. J., and Thompson, T.B., ed., Guidebook to field trips in western New Hampshire and adjacent Vermont and Massachusetts, 104th New England Intercollegiate Geological Conference, Mount Sunapee, New Hampshire, p. A4-1-A4-21.

Whalen, J. B., Jenner, G. A., Currie, K. L., Barr, S. M., Longstaffe, F. J., and Hegner, E., 1994, Geochemical and isotopic characteristics of granitoids of the Avalon Zone, southern New Brunswick: possible evidence for repeated delamination events: The Journal of Geology, v. 102, no. 3, p. 269-282.

White, W. S., and Jahns, R. H., 1950, Structure of central and east-central Vermont: The Journal of Geology, p. 179-220.

Whitehead, J., Reynolds, P. H., and Spray, J. G., 1995, The sub-ophiolitic metamorphic rocks of the Québec Appalachians: Journal of Geodynamics, v. 19, no. 3, p. 325350 .

Wiedenbeck, M., Alle, P., Corfu, F., Griffin, W., Meier, M., Oberli, F. v., Quadt, A. v., Roddick, J., and Spiegel, W., 1995, Three natural zircon standards for $\mathrm{U}-\mathrm{Th}-\mathrm{Pb}, \mathrm{Lu}-\mathrm{Hf}$, trace element and REE analyses: Geostandards and Geoanalytical Research, v. 19, no. 1, p. 1-23.

Williams, H., 1979, Appalachian orogen in Canada: Canadian Journal of Earth Sciences, v. 16 , no. 3 , p. $792-807$.

-, 1995, Geology of the Appalachian-Caledonian orogen in Canada and Greenland, Geological Survey of Canada 944 p.

Wilson, R. A., and Kamo, S. L., 2016, Geochronology and lithogeochemistry of granitoid rocks from the central part of the Central plutonic belt, New Brunswick, Canada: implications for Sn-W-Mo exploration: Atlantic Geology, v. 52, p. 125-167.

Zen, E.-a., Goldsmith, R., Ratcliffe, N. M., Robinson, P., Stanley, R. S., Hatch, N. L., Shride, A. F., Weed, E. G. A., and Wones, D. R., 1983, Bedrock geologic map of Massachusetts: , U.S. Geological Survey, scale 1:250,000. 


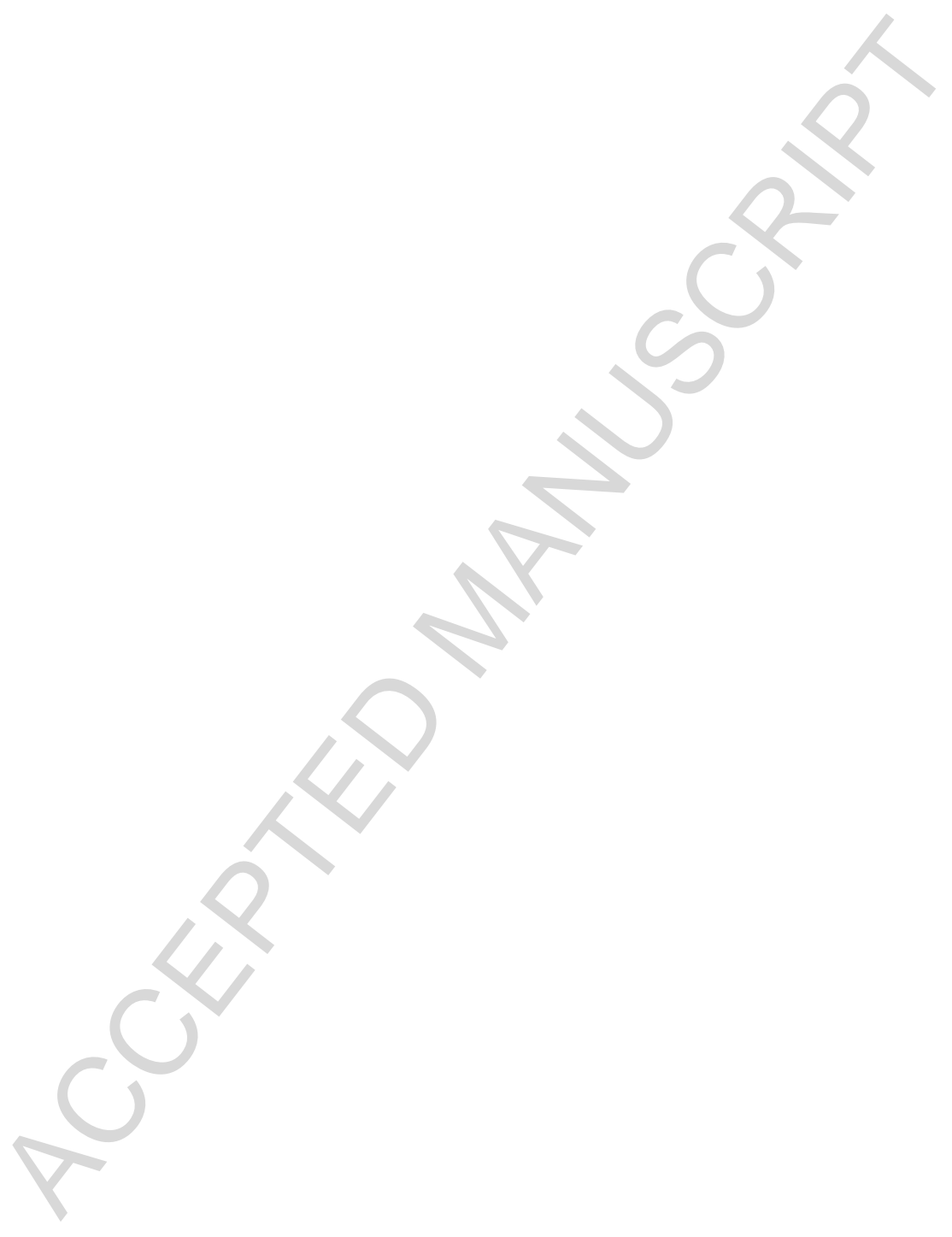




\section{Highlights}

- Transition of orogenic cycles reflected by timing of deposition, along-strike paleo-geographic variations and nature of erosional sources of syn-orogenic basin.

- Implication of approaching Avalonian terranes in the transition from Salinic to Acadian orogenic cycles

- Detrital zircon U-Pb geochronology highlights that the Gaspé Belt and Connecticut Valley sequence yielded maximum age of deposition of c. $413 \mathrm{Ma}$ and c. $401 \mathrm{Ma}$, respectively.

- Detrital muscovite ${ }^{40} \mathrm{Ar} /{ }^{39} \mathrm{Ar}$ geochronology results highlight the contribution of erosional sources having experienced Grenvillian, Taconian and Salinic metamorphism.

- U-Pb cristallisation age of the Averill Pluton is $367.8 \pm 0.3 \mathrm{Ma}$ 
ROCKS UNITS OUTSIDE THE CVGT Plutonic rocks

${ }_{t^{+}+}$Devonian/Post-Devonian

Ordovician/Silurian

Upper Ordovician - Lower Silurian

Gaspé Belt

Upper Silurian

Upper Magog Gp.

Pre-Silurian rock units

Dunnage zone
$\square$ sedimentary rocks

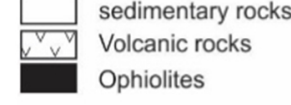

Humber zone

60] External
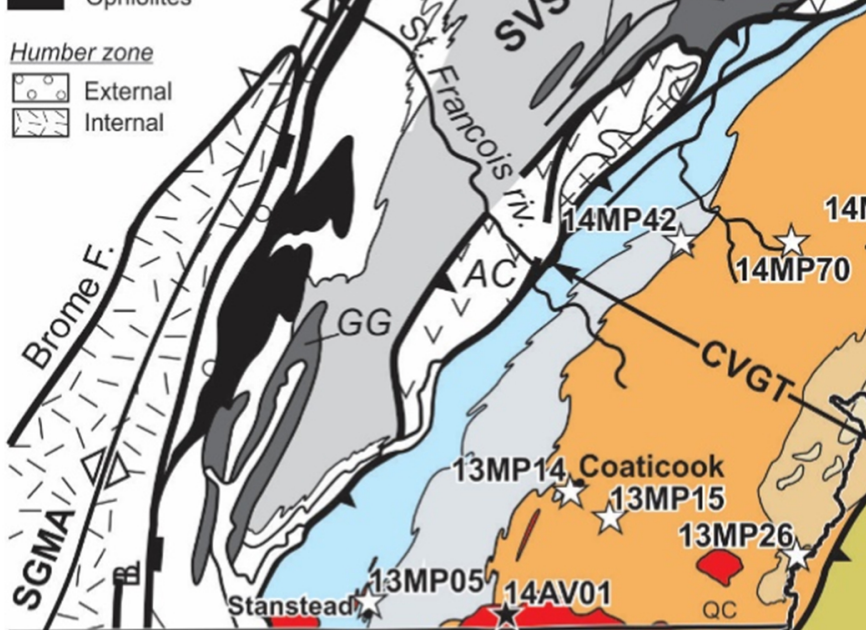

QC$$
\text { . }
$$
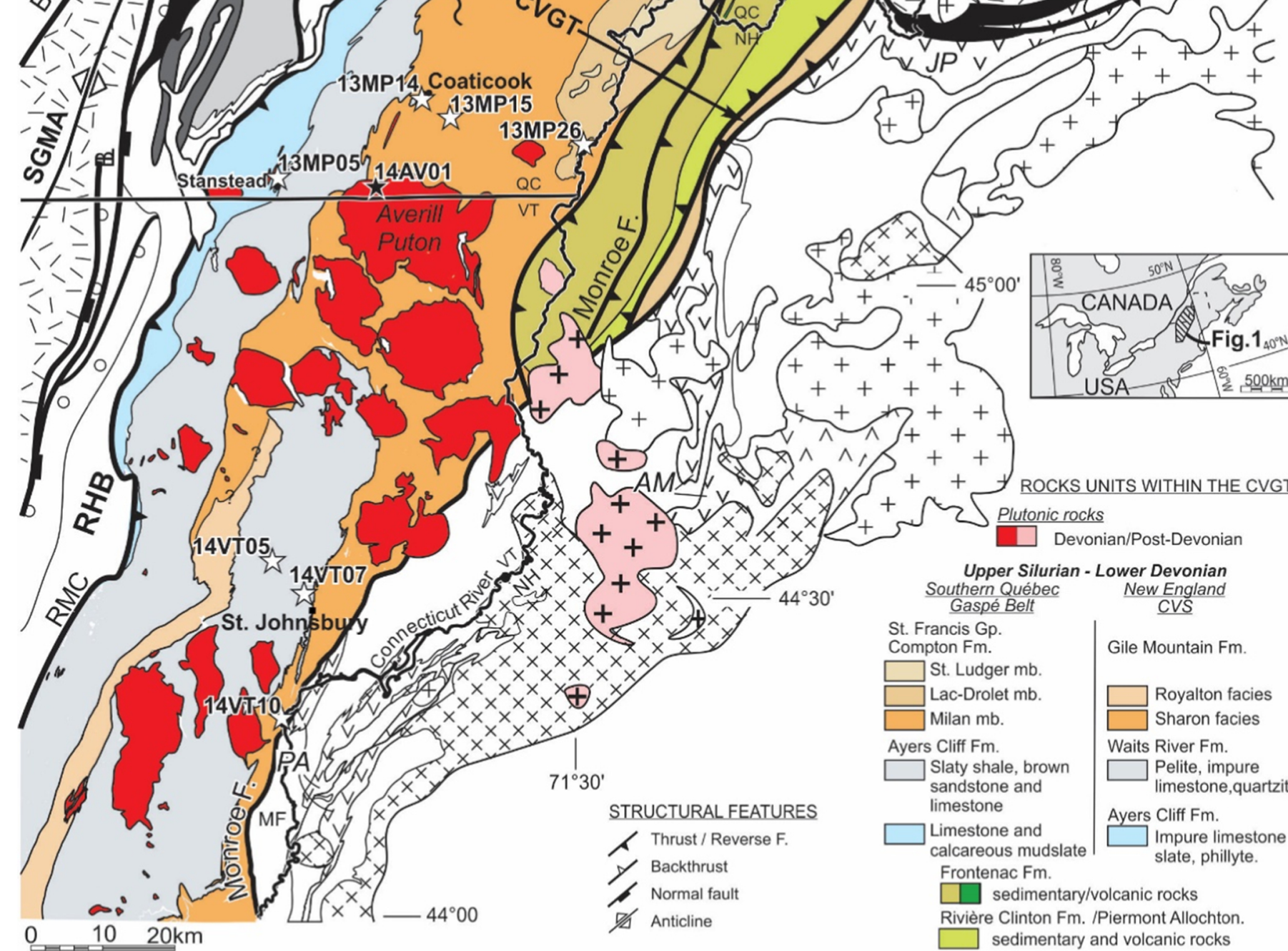


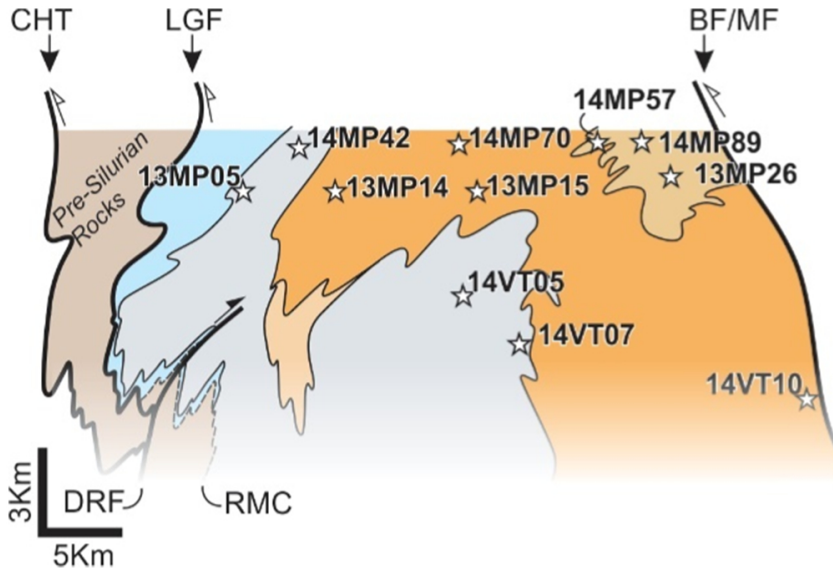

Figure 2 


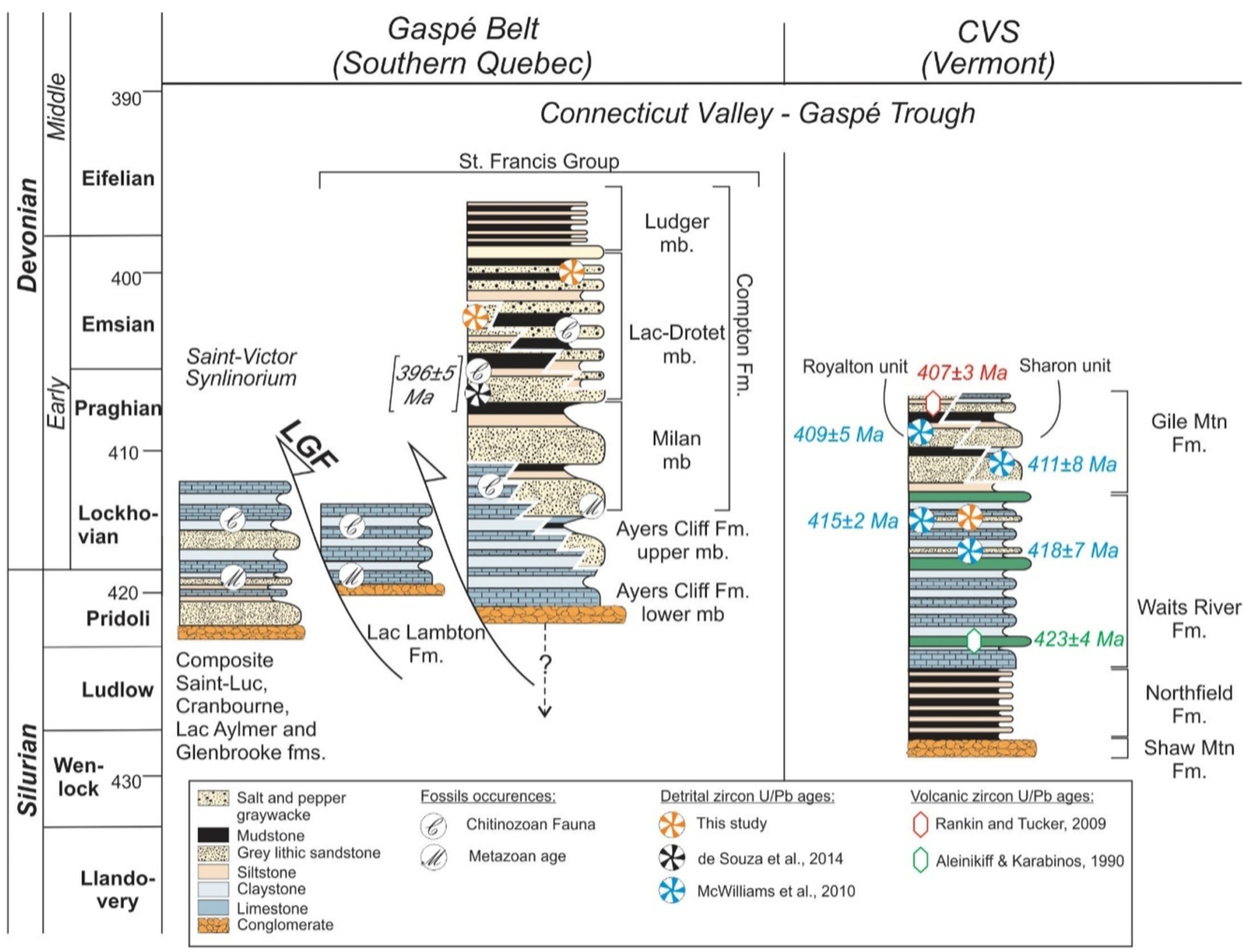



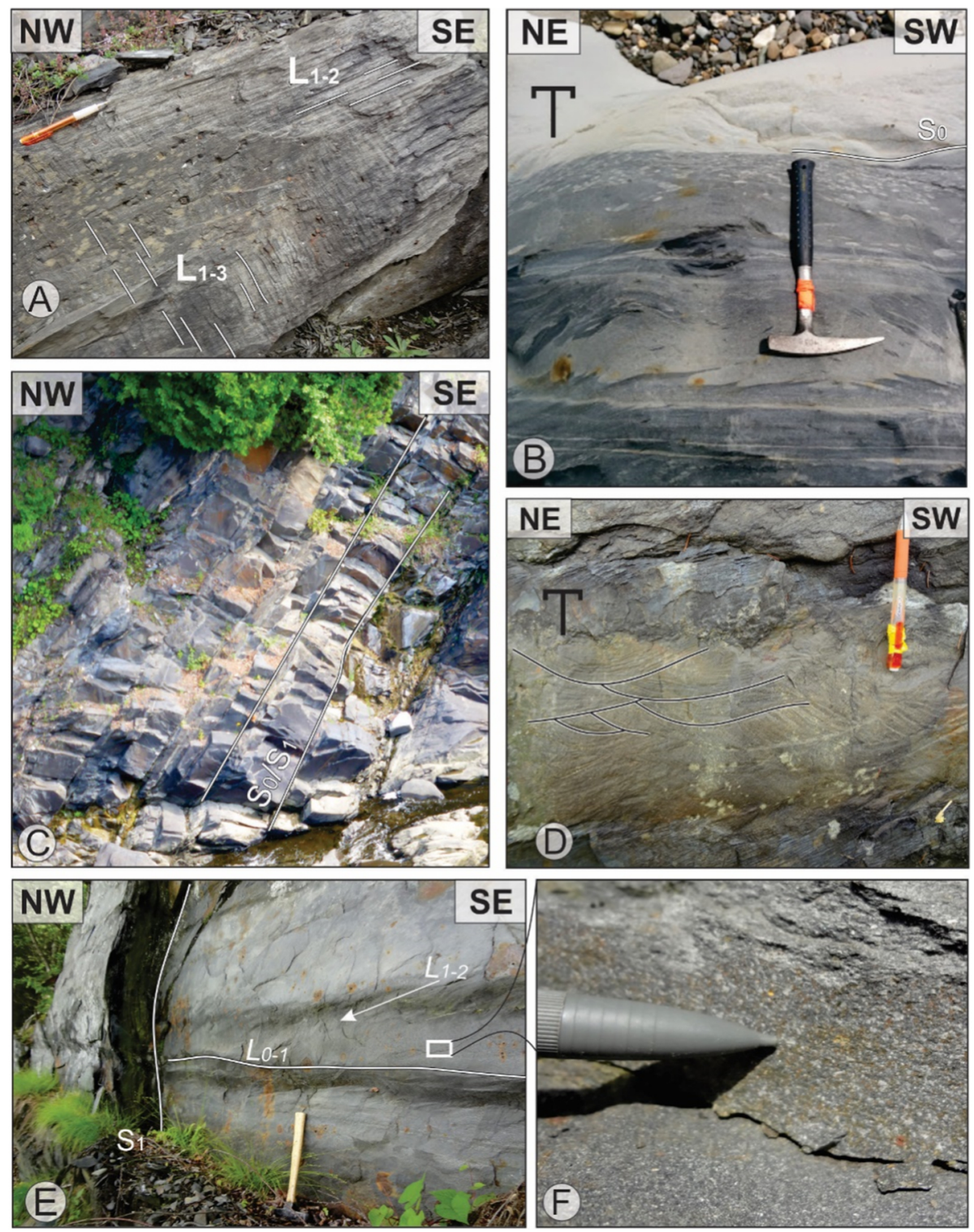

Figure 4 


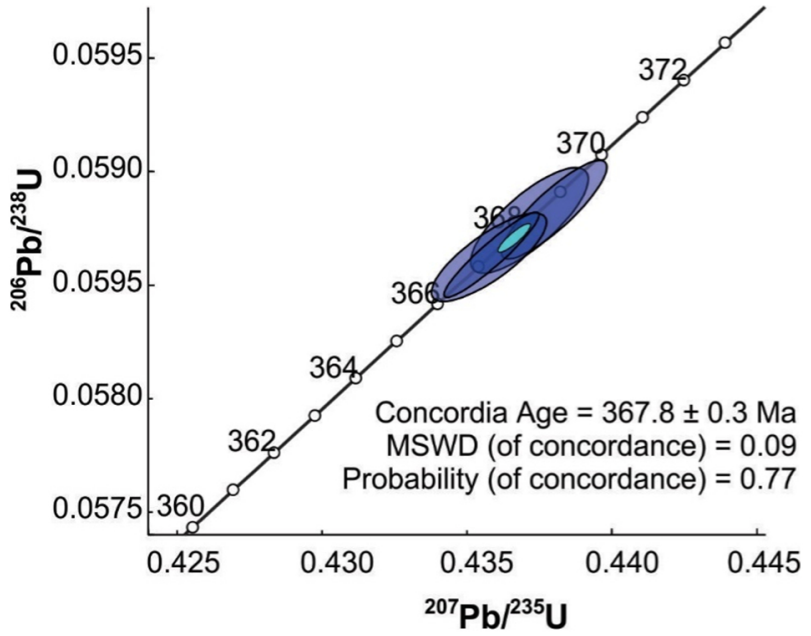

Figure 5 
(A) Ayer's Cliff Fm. 14MP42 35
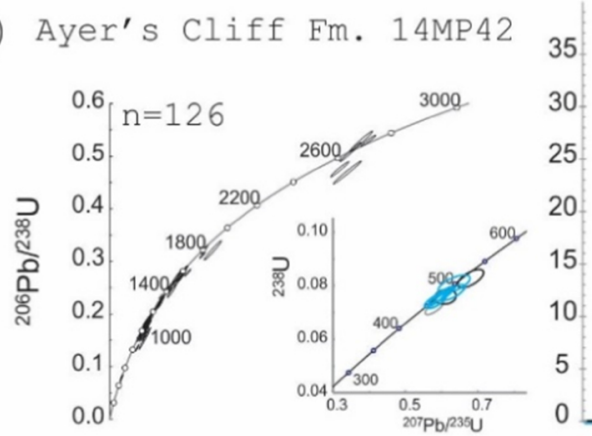

(B) Milan mb.14MP70
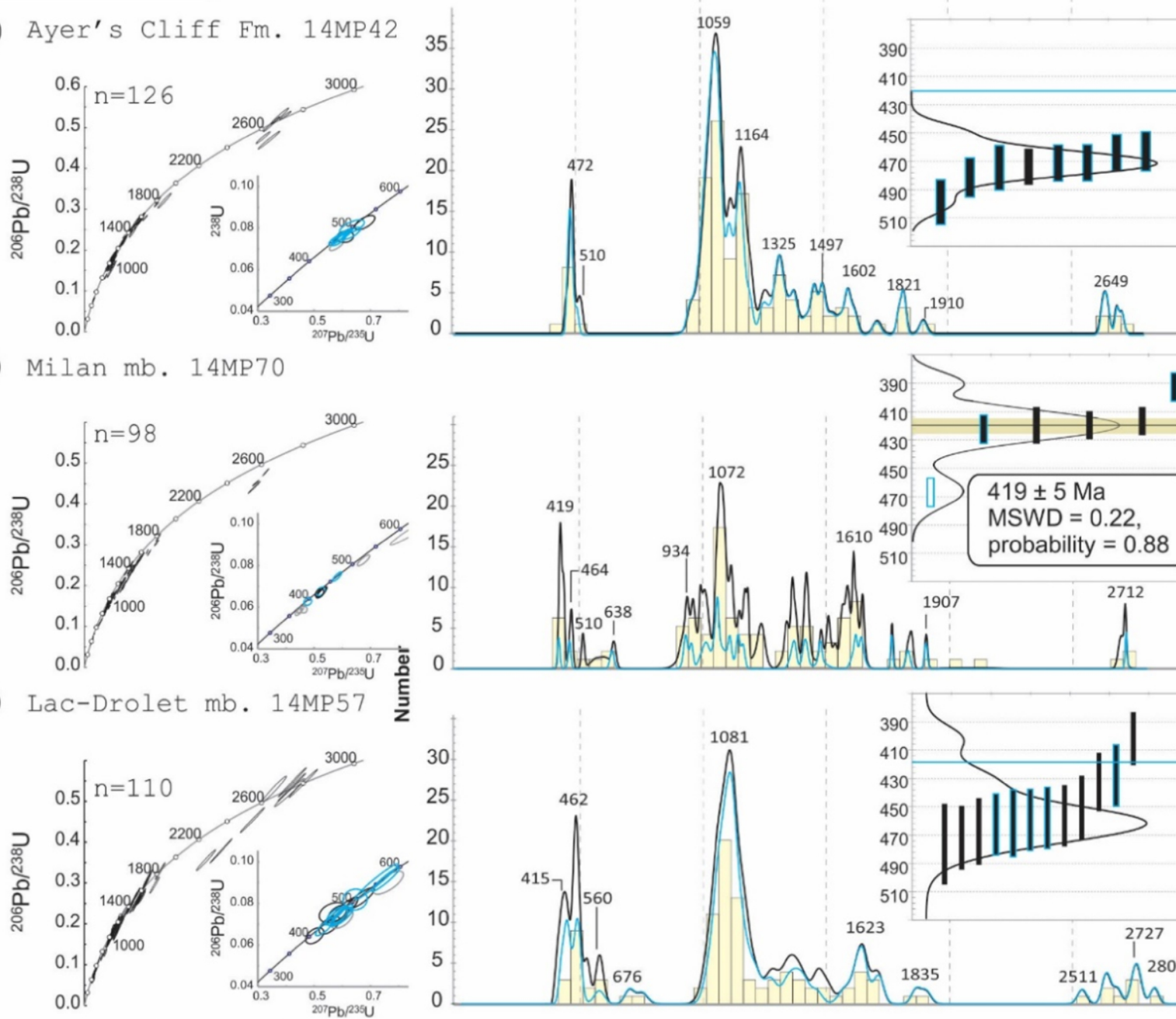

(C) Lac-Drolet mb.14MP5

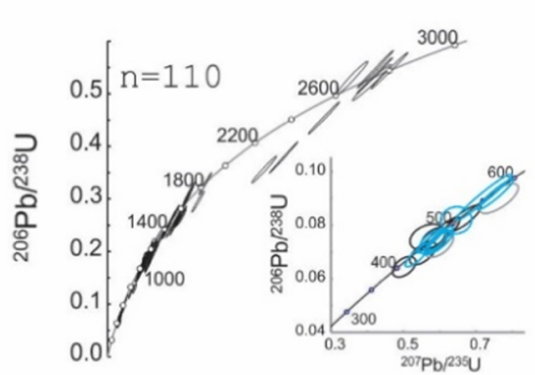

(D) Lac Drolet mb. 14MP89
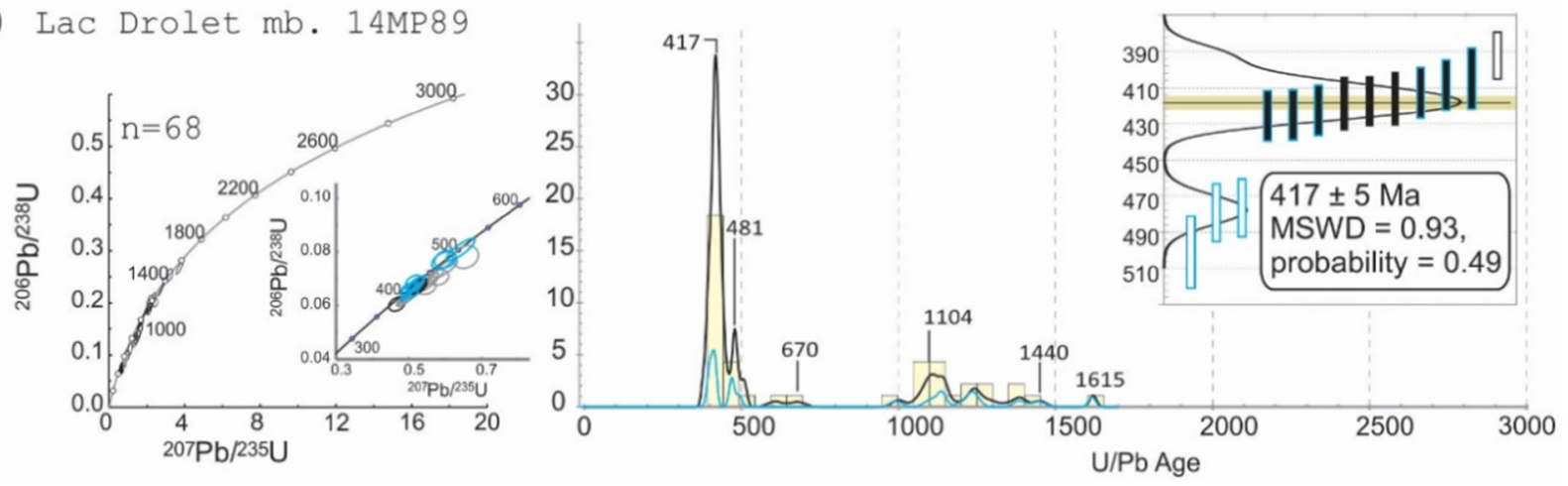
Coaticook transect

(A) Ayer's Cliff Fm. 13MP05
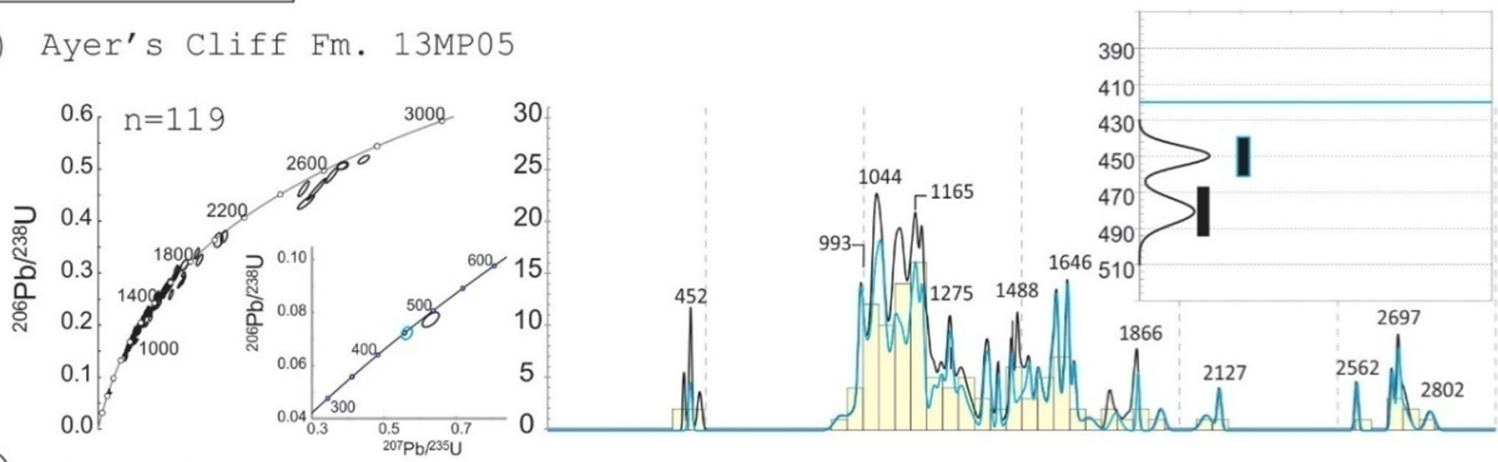

(B) Milan mb. 13MP14
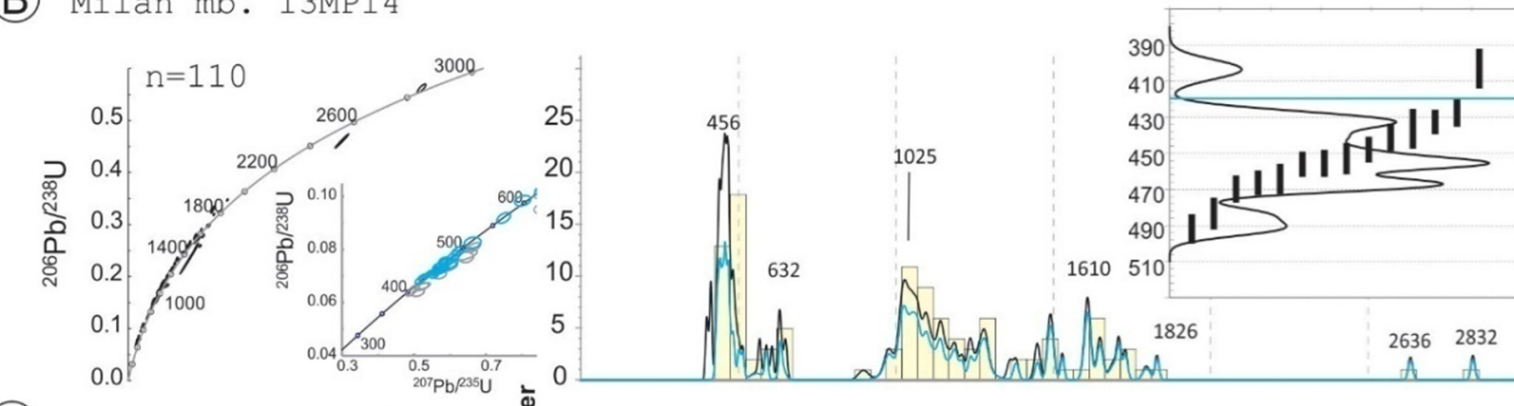

(C) Milan mb. 13MP15

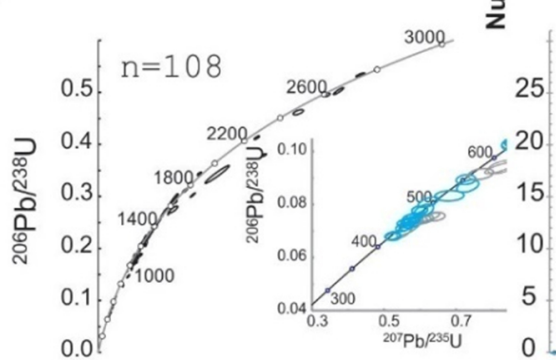

(D) Lac-Drolet mb. 13 MP26
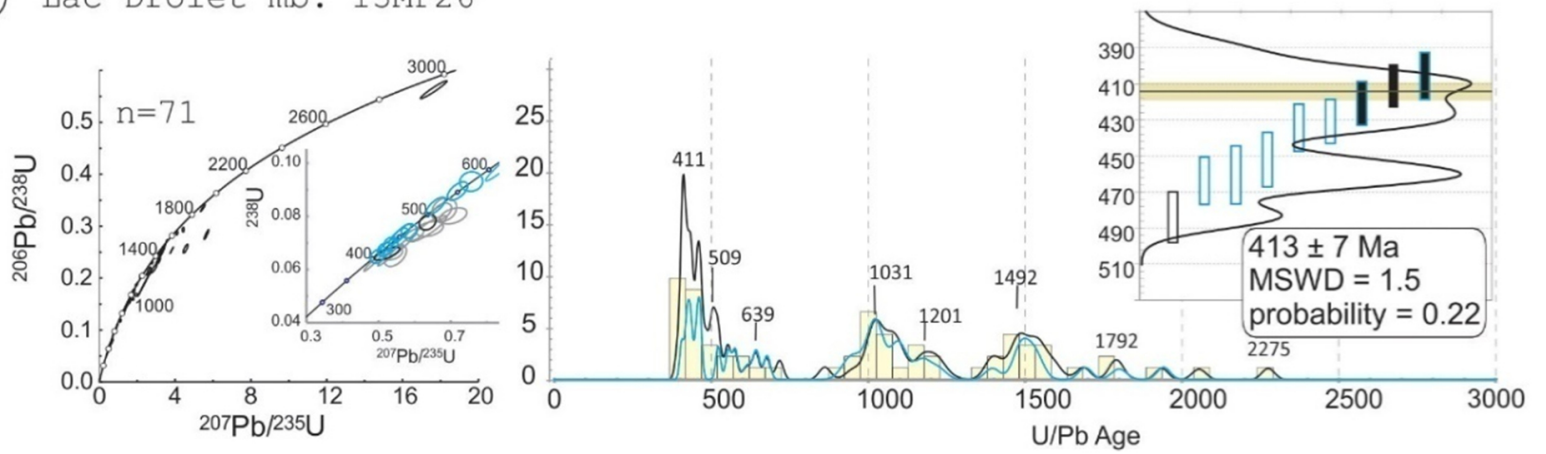

Figure 7 
St. Johnsbury transect

(A) Waits River Fm. 14VT05
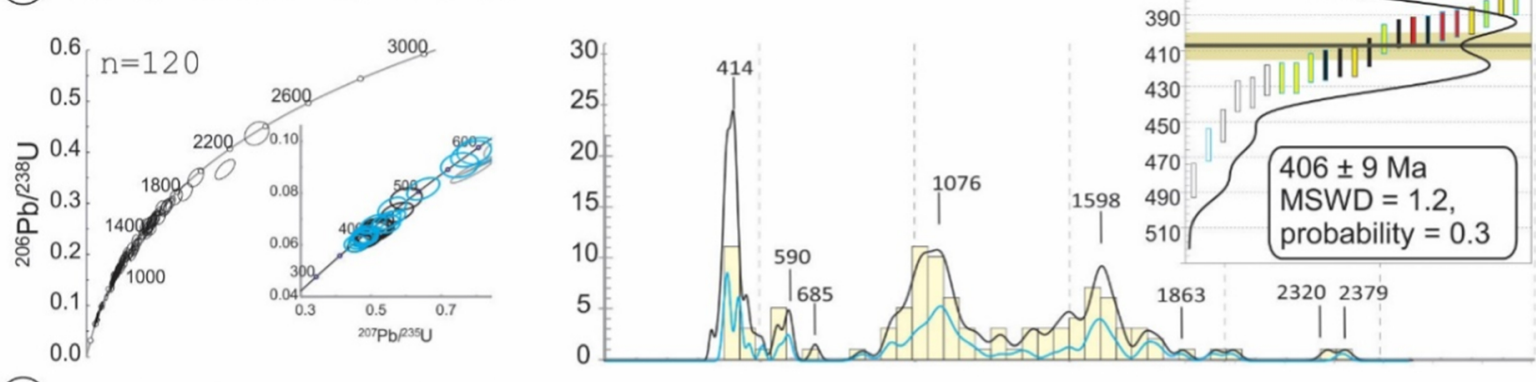

(B) Waits River Fm. 14VT07
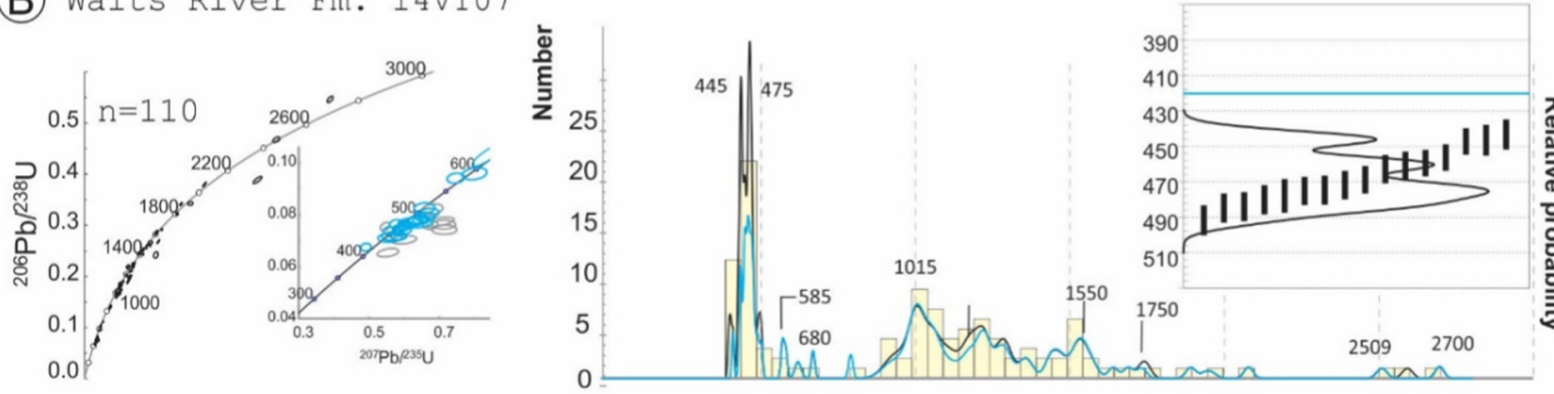

(C) Gile Mountain Fm. 14VT10
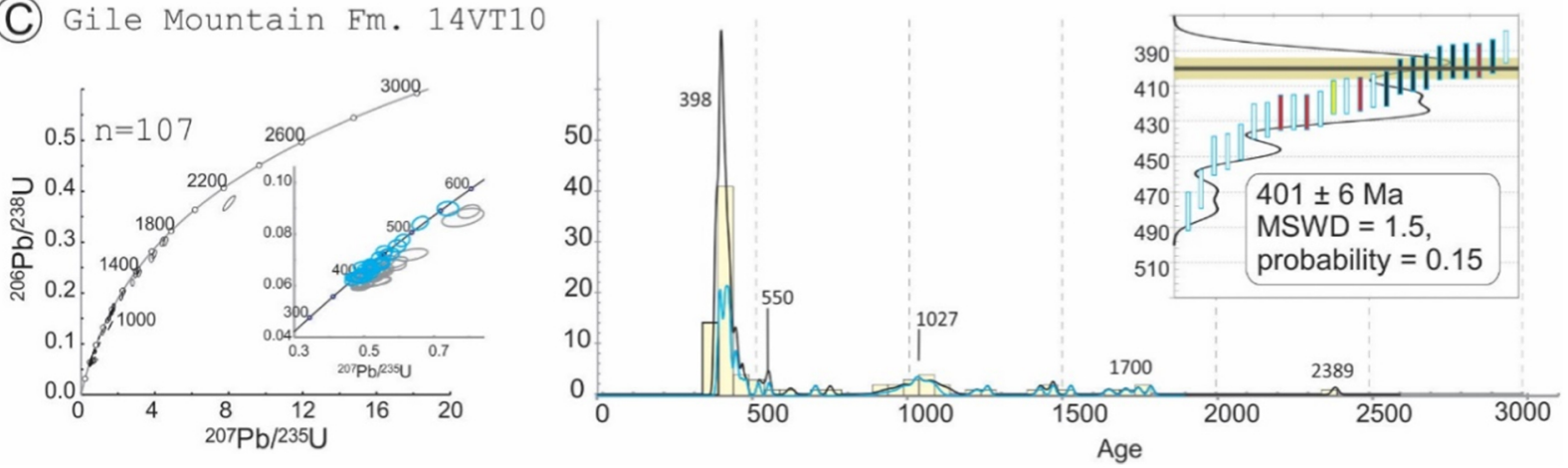

Figure 8 


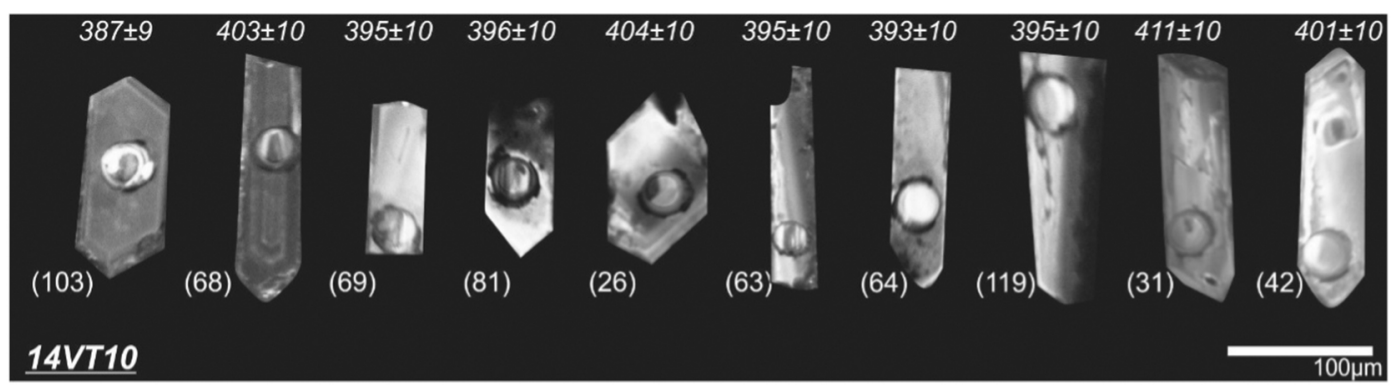

Figure 9 


\section{Ayer's Cliff Formation}

(A) $14 \mathrm{MP} 42$

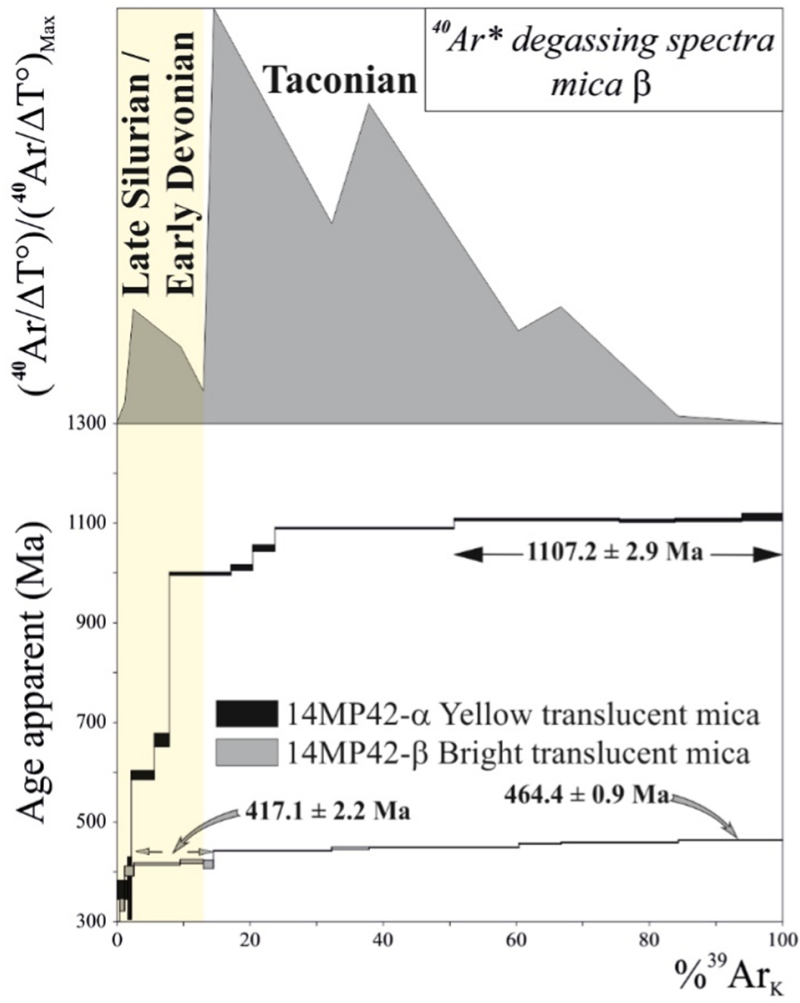

(B) $\quad 13 \mathrm{MPO} 5$

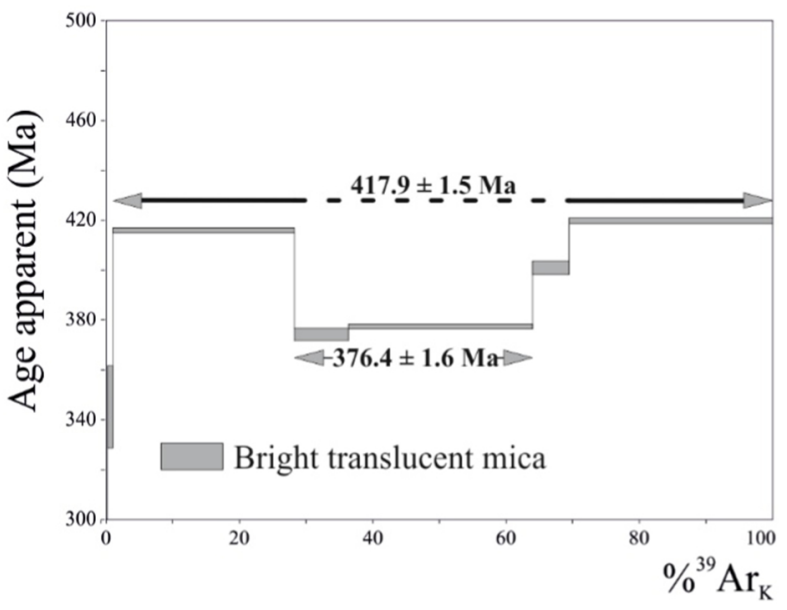


(A) $14 \mathrm{MP} 70$

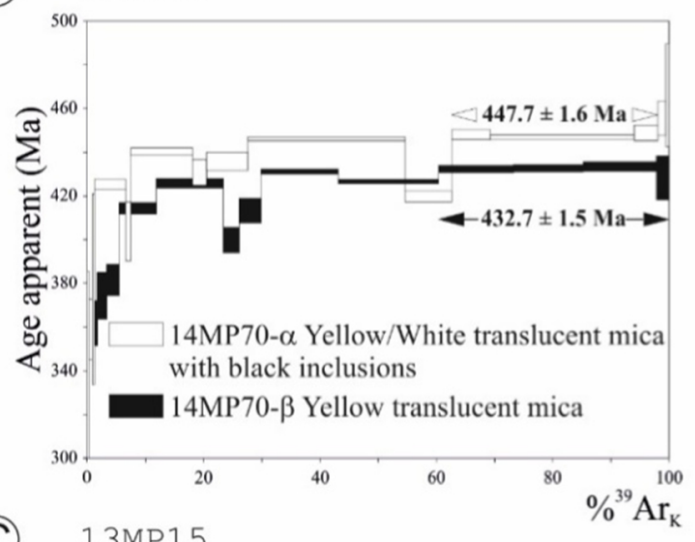

(C) $13 \mathrm{MP} 15$

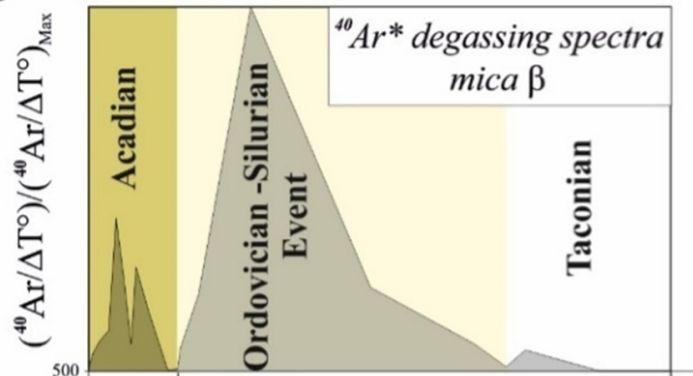

(B) 13MP14

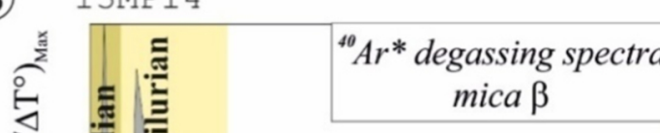
mica $\beta$

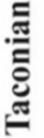

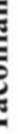

起

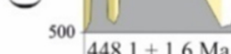

$459.8 \pm 1.6 \mathrm{Ma}$

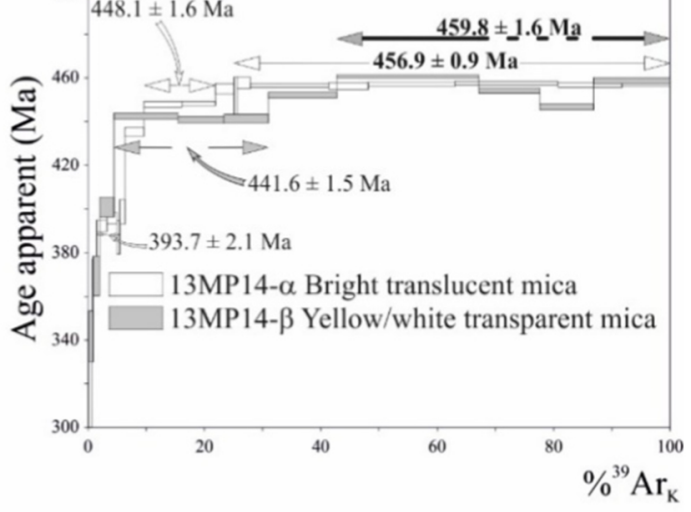

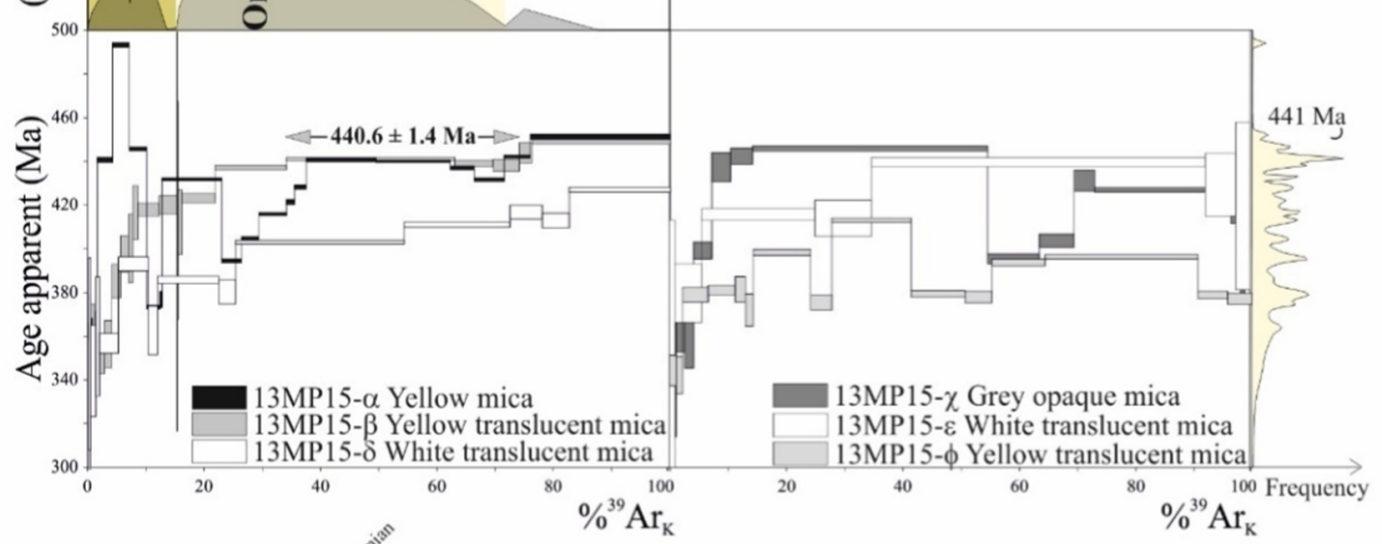

(D)

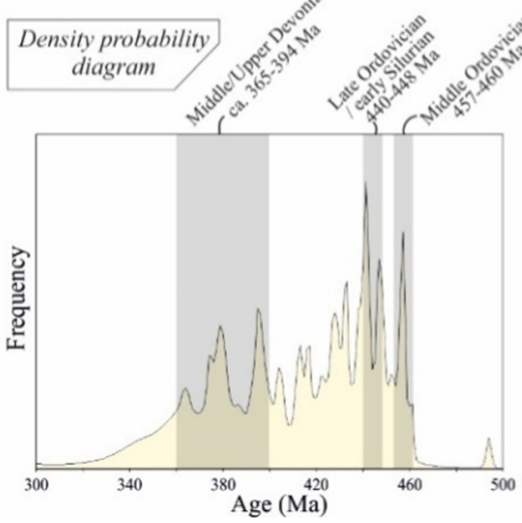


Compton Formation - Lac-Drolet member

(A) $14 \mathrm{MP} 89$

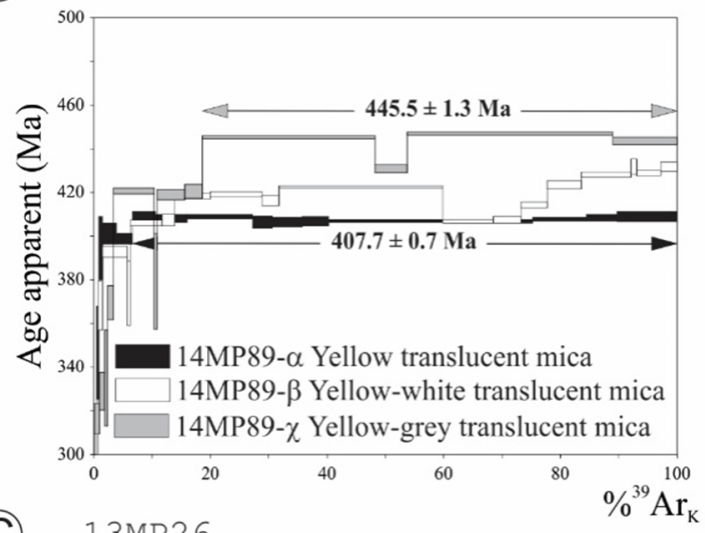

(C) $13 \mathrm{MP} 26$

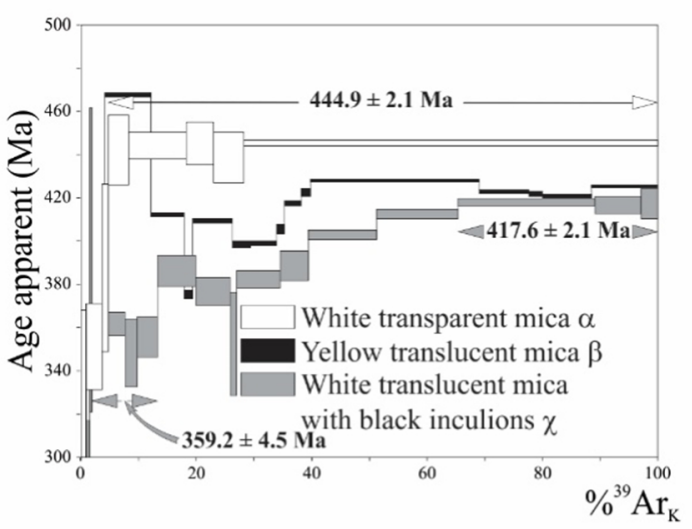

(D)
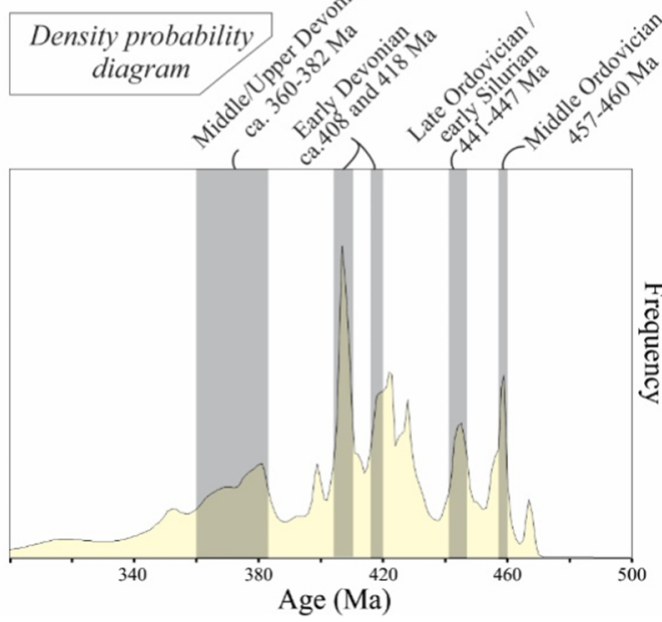

(B) 14MP5 7
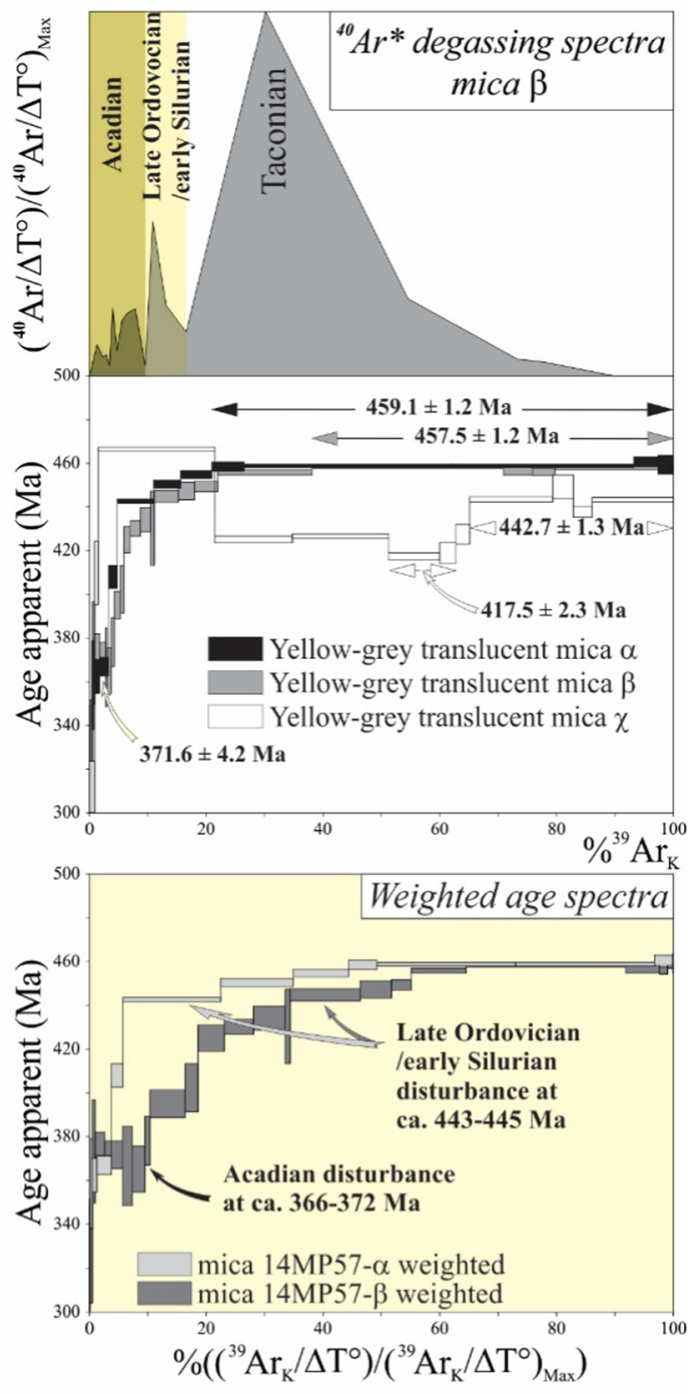

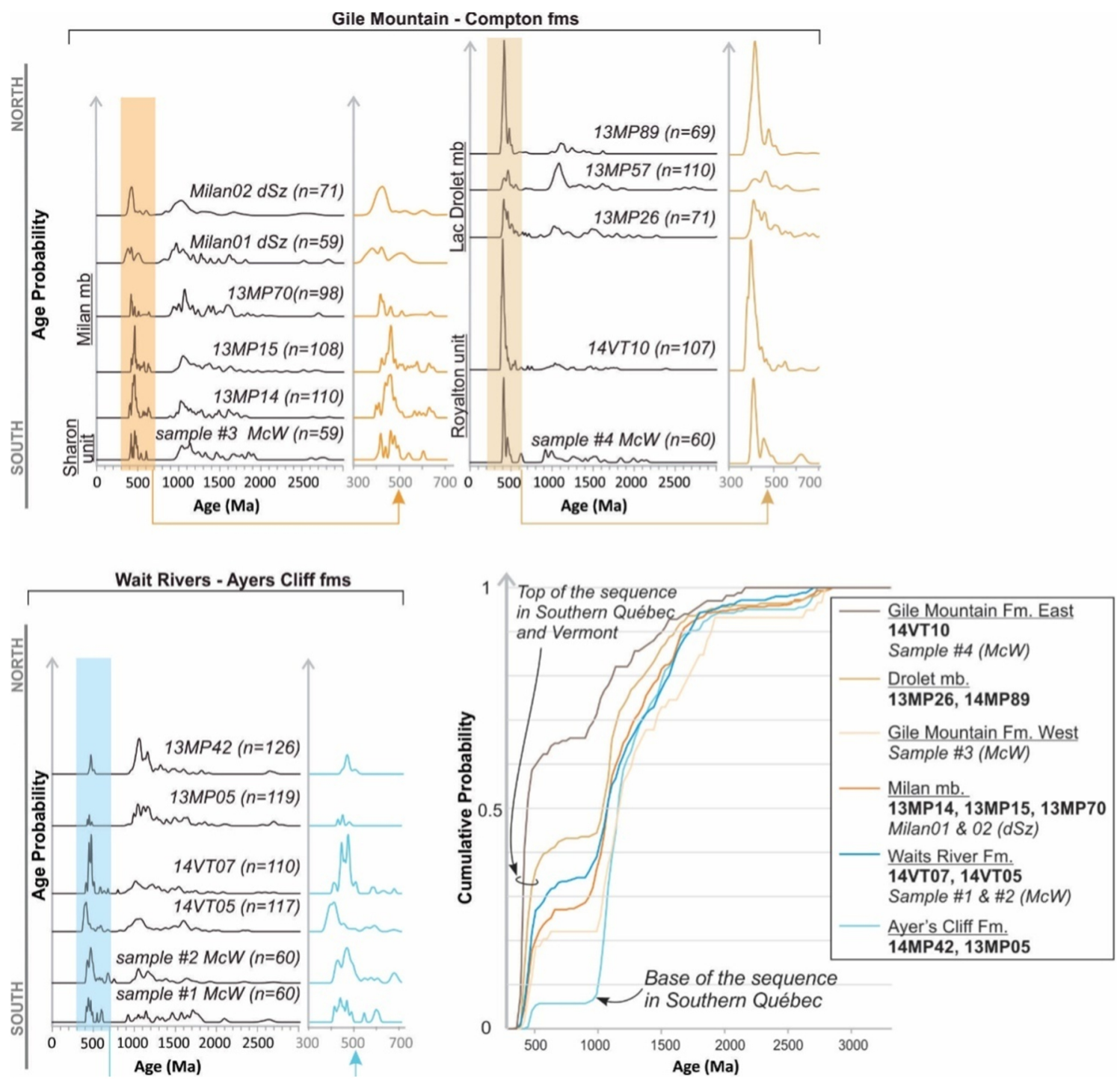

Figure 13 


\section{Connecticut Valley-Gaspé Trough}

Southern Québec

Vermont

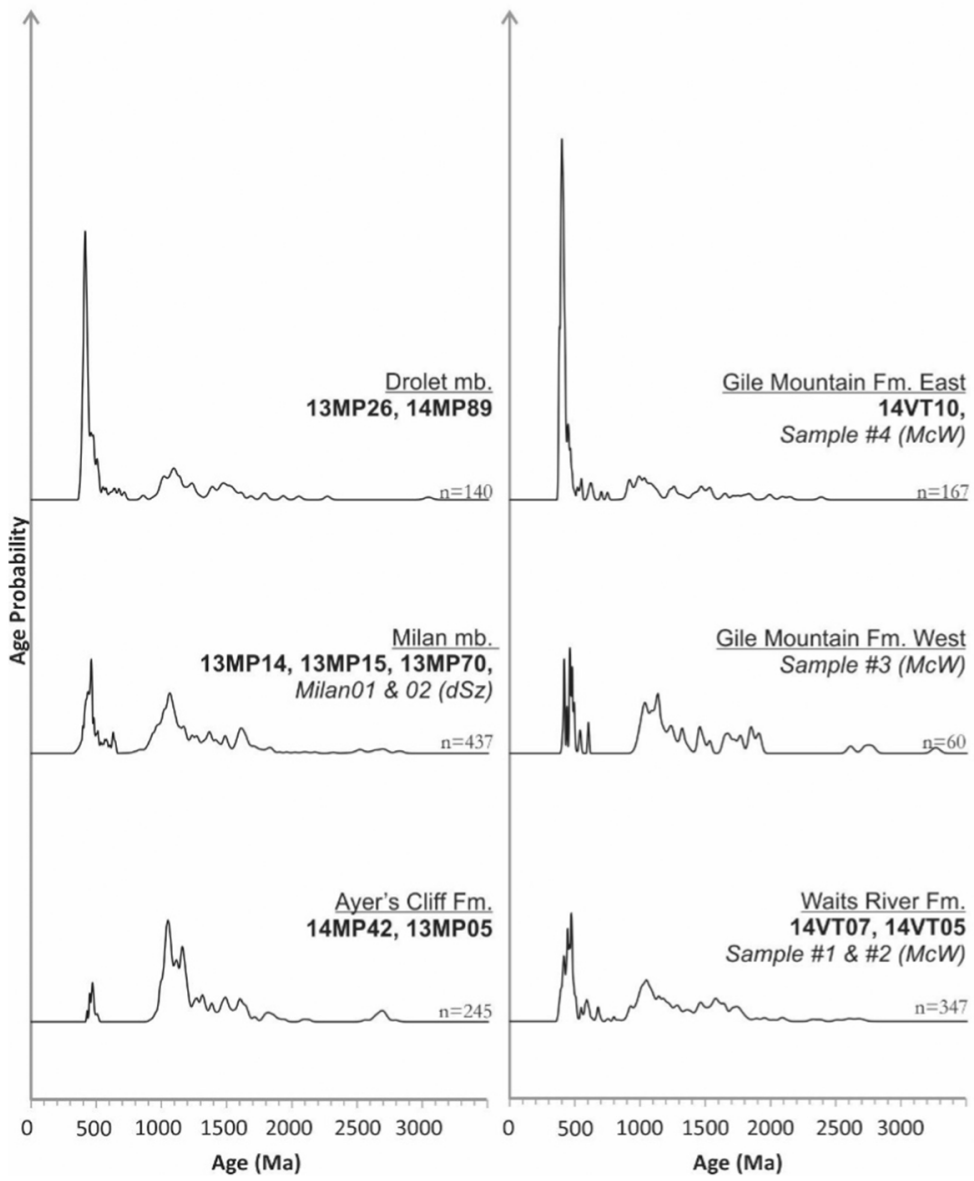

\section{Central Maine Basin}

Maine

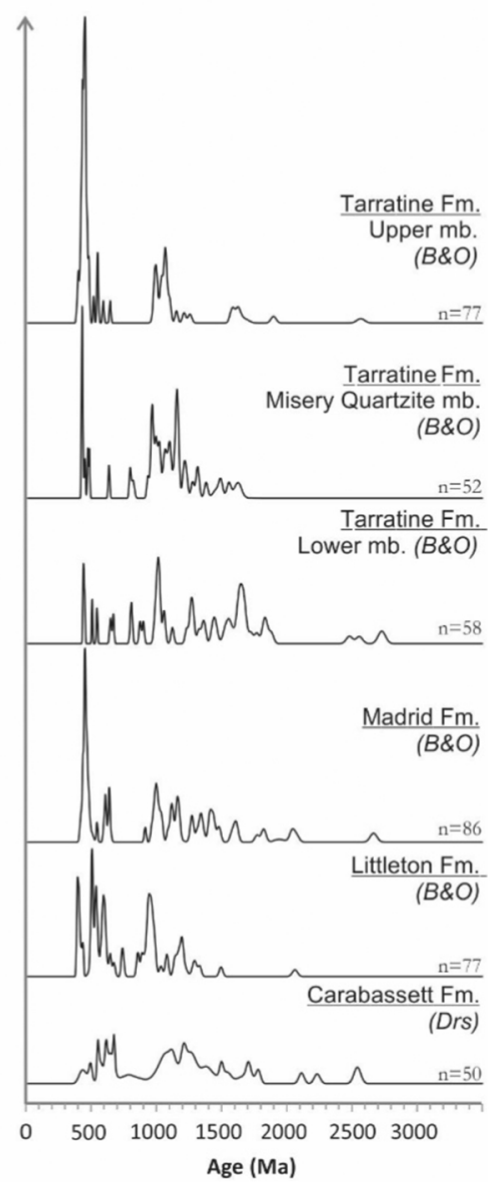

Figure 14 


\section{5-425 Ma}

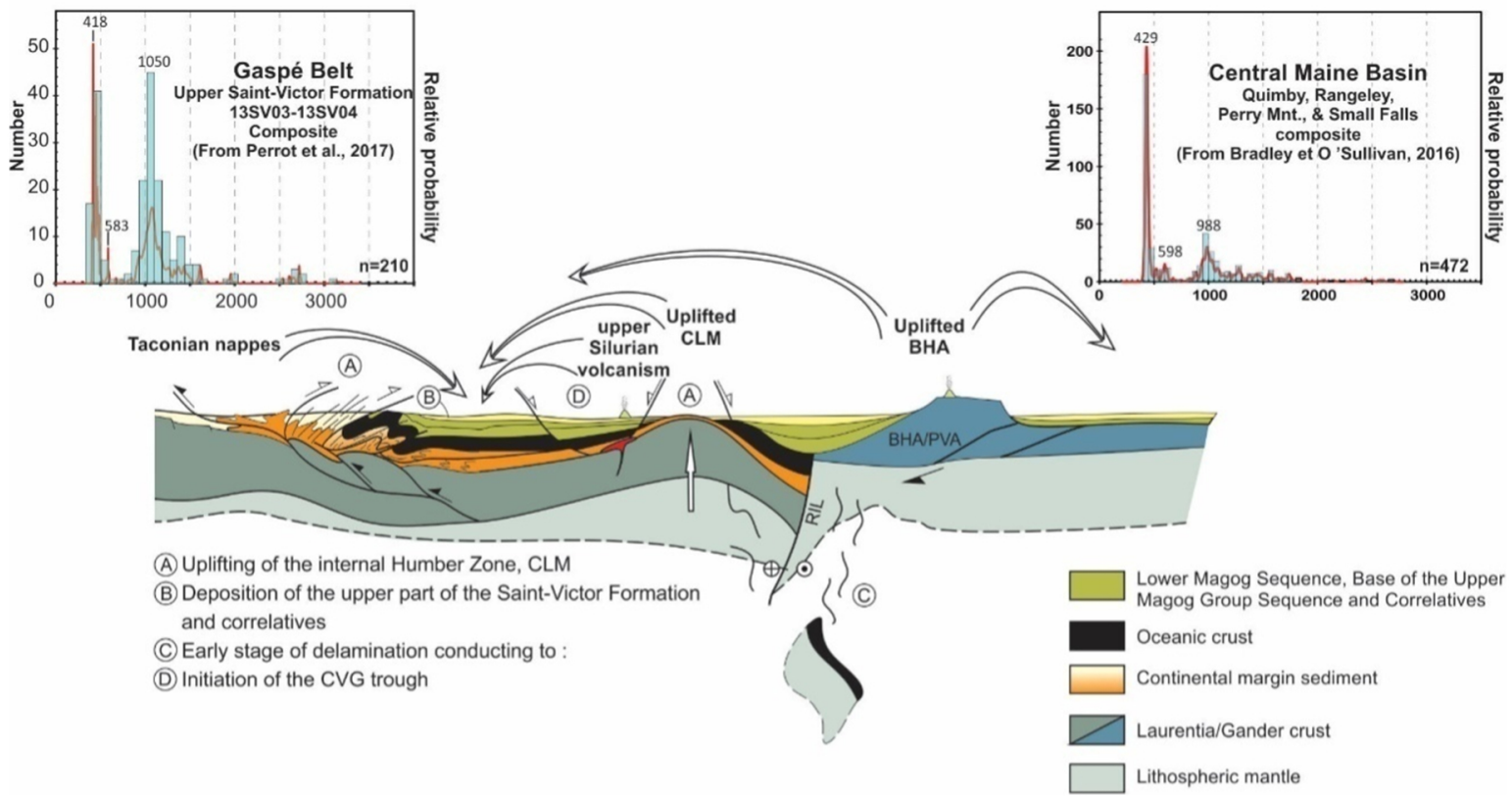




\section{A. $425-410 \mathrm{Ma}$}
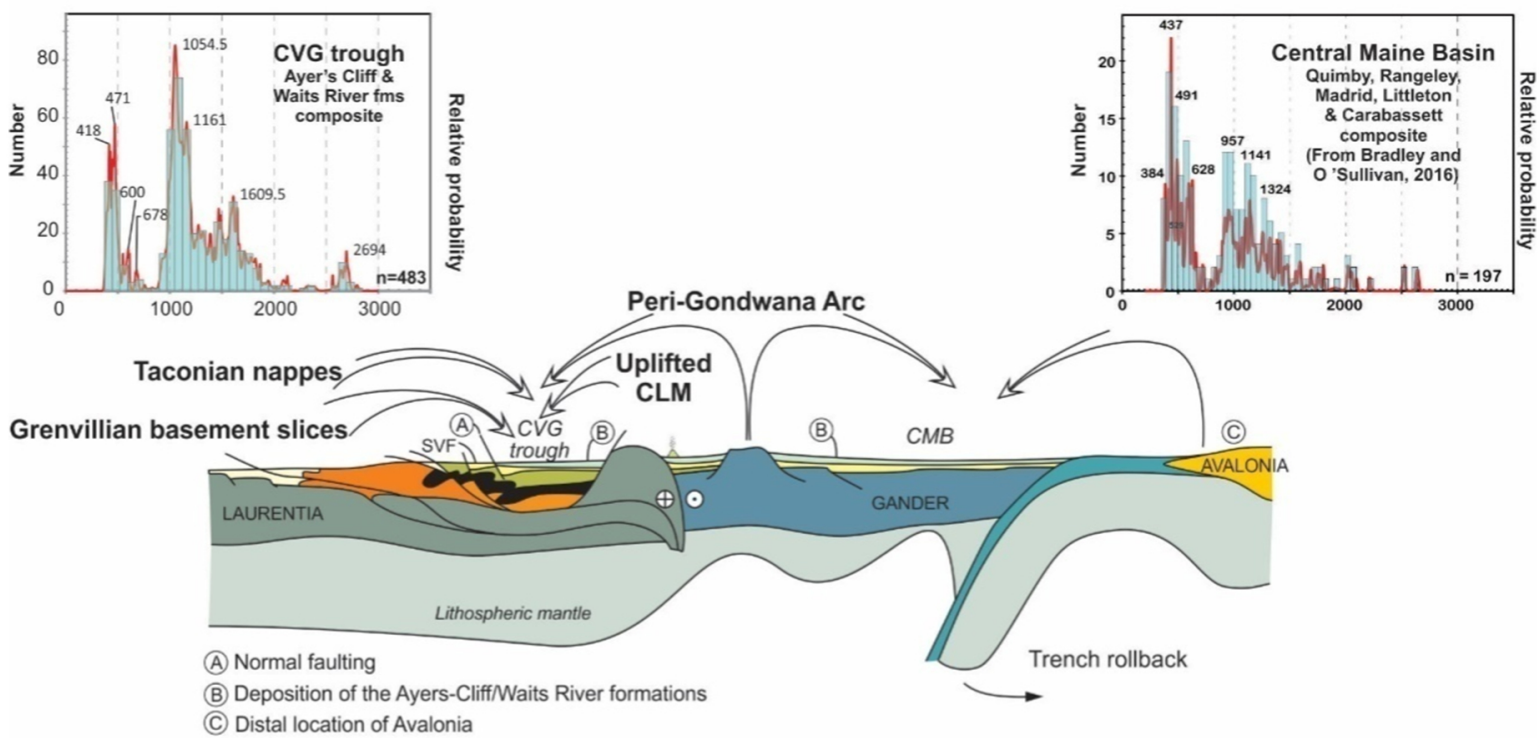

\section{B. $410-395 \mathrm{Ma}$}

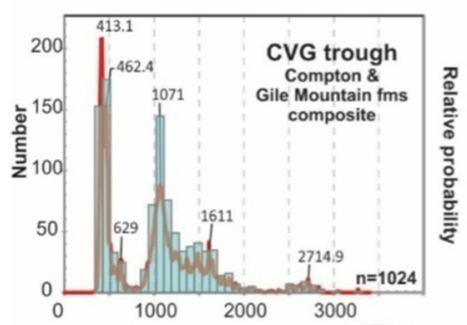

Taconian nappes

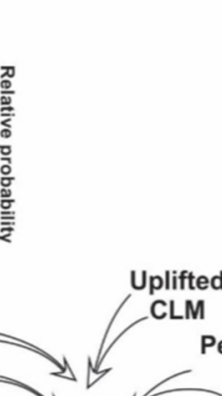

Peri-Gondwana arc \& Lower-Devonian Volcanism

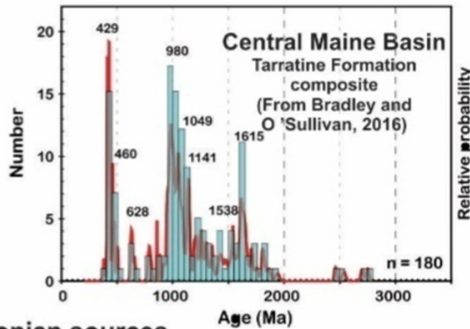

Grenvillian basement slices

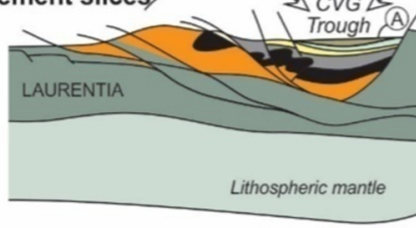

(A) Deposition of the Comtpon/Gile Mountain formations

(B) Approch of Avalonia 